\title{
Predictive value of S-100ß protein for prognosis in patients with moderate and severe traumatic brain injury: systematic review and meta-analysis
}

\author{
(c) $(1)$ (8)
}

\begin{abstract}
Eric Mercier MSc candidate ${ }^{1}$, Amélie Boutin PhD candidate ${ }^{1}$, François Lauzier assistant professor ${ }^{123}$, Dean A Fergusson associate professor ${ }^{4}$, Jean-François Simard research assistant ${ }^{1}$, Ryan Zarychanski assistant professor ${ }^{5}$, Lynne Moore assistant professor ${ }^{16}$, Lauralyn A Mclntyre assistant professor $^{47}$, Patrick Archambault assistant professor ${ }^{8}$, François Lamontagne assistant professor ${ }^{9}$, France Légaré professor ${ }^{810}$, Edward Randell associate professor ${ }^{11}$, Linda Nadeau assistant professor $^{12}$, François Rousseau professor ${ }^{1012}$, Alexis F Turgeon assistant professor ${ }^{12}$
\end{abstract}

\begin{abstract}
${ }^{1}$ Centre de Recherche du Centre Hospitalier Universitaire (CHU) de Québec (Hôpital de l'Enfant-Jésus), Traumatologie - Urgence - Soins Intensifs (Trauma - Emergency - Critical Care Medicine), Université Laval, Québec City, QC, Canada; ${ }^{2}$ Department of Anesthesiology, Division of Critical Care, Université Laval, Québec City, QC, Canada; ${ }^{3}$ Department of Medicine, Université Laval, Québec City, QC, Canada; ${ }^{4}$ Clinical Epidemiology Unit, Ottawa Hospital Research Institute, Ottawa, ON, Canada; ${ }^{5}$ Department of Internal Medicine, Section of Critical Care Medicine, University of Manitoba, Winnipeg, MB, Canada; ${ }^{6}$ Department of Social and Preventive Medicine, Université Laval, Québec, QC, Canada; ${ }^{7}$ Department of Medicine, Division of Critical Care, University of Ottawa, Ottawa, ON Canada; ${ }^{8}$ Department of Family and Emergency Medicine, Université Laval, Québec, QC, Canada; ${ }^{9}$ Centre de Recherche Clinique Étienne-Le Bel du CHUS, Université de Sherbrooke, Sherbrooke, QC, Canada; ${ }^{10} \mathrm{Centre} \mathrm{de} \mathrm{Recherche}$ du CHU de Québec, Knowledge Transfer and Health Technology Assessment, Université Laval, Québec City, QC, Canada; ${ }^{11}$ Department of Laboratory Medicine, Memorial University, St John's, NF, Canada; ${ }^{12}$ Department of Molecular Biology, Medical Biochemistry and Pathology, Université Laval, Québec City, QC, Canada
\end{abstract}

\begin{abstract}
Objectives To determine the ability and accuracy of the S-100 $\beta$ protein in predicting prognosis after a moderate or severe traumatic brain injury.

Design Systematic review and meta-analysis of randomised controlled trials and observational studies.

Data sources Medline, Embase, Cochrane Central Register of Controlled Trials, BIOSIS (from their inception to April 2012), conference abstracts, bibliographies of eligible articles, and relevant narrative reviews.

Study selection Two reviewers independently reviewed citations and selected eligible studies, defined as cohort studies or randomised control trials including patients with moderate or severe traumatic brain injury and evaluating the prognostic value of $S-100 \beta$ protein. Outcomes evaluated were mortality, score on the Glasgow outcome scale, or brain death.
\end{abstract}

Data extraction Two independent reviewers extracted data using a standardised form and evaluated the methodological quality of included studies. Pooled results were presented with geometric means ratios and analysed with random effect models. Prespecified sensitivity analyses were performed to explain heterogeneity.

Results The search strategy yielded 9228 citations. Two randomised controlled trials and 39 cohort studies were considered eligible (1862 patients). Most studies ( $n=23$ ) considered Glasgow outcome score $\leq 3$ as an unfavourable outcome. All studies reported at least one measurement of $S-100 \beta$ within 24 hours after traumatic brain injury. There was a significant positive association between $S-100 \beta$ protein concentrations and mortality (12 studies: geometric mean ratio 2.55 , $95 \%$ confidence interval 2.02 to $3.21, l^{2}=56 \%$ ) and score $\leq 3$ ( 18 studies: $2.62,2.01$ to $\left.3.42, I^{2}=79 \%\right)$. Sensitivity analysis based on sampling time, 
sampling type, blinding of outcome assessors, and timing of outcome assessment yielded similar results. Thresholds for serum S-100ß protein values with $100 \%$ specificity ranged from 1.38 to $10.50 \mu \mathrm{g} / \mathrm{L}$ for mortality (six studies) and from 2.16 to $14.00 \mu \mathrm{g} / \mathrm{L}$ for unfavourable neurological prognosis as defined by the Glasgow outcome score.

Conclusions After moderate or severe traumatic brain injury, serum S-100ß protein concentrations are significantly associated with unfavourable prognosis in the short, mid, or long term. Optimal thresholds for discrimination remain unclear. Measuring the S-100ß protein could be useful in evaluating the severity of traumatic brain injury and in the determination of long term prognosis in patients with moderate and severe injury.

\section{Introduction}

Early determination of prognosis after traumatic brain injury is a priority for relatives and physicians involved in the care of these patients. ${ }^{12}$ Despite recent improvement in management of patients with traumatic brain injury in intensive care and the development of guidelines to standardise care, ${ }^{34}$ mortality and morbidity in these patients remain high. ${ }^{5-7}$ About $30 \%$ of patients admitted after severe traumatic brain injury will die, and 50\% will be moderately disabled. ${ }^{78}$ In a recent multicentre cohort study, we observed variable mortality rates across Canadian trauma centres, despite comparable severity of injury, and considerable variation in the incidence of withdrawal of life sustaining treatments. ${ }^{9}$ As many of these patients are young with no previous comorbidity, the decision to withdraw life sustaining treatments is based mainly on prognostic evaluation. Current prognostic indicators and models, however, are limited by their lack of sufficient discriminative capacity to inform clinical decision making. ${ }^{10-12}$ New prognostic information beyond the clinical examination, patient demographics, and radiological imaging from admission is needed to allow early prediction of short, mid, and long term outcome of patients with moderate and severe traumatic brain injury. ${ }^{13}$

Over the past 20 years, biochemical markers of brain damage have been increasingly studied as potential tools for prognostic evaluation. ${ }^{13-17}$ Concentrations of S-100 $\beta$ protein, the $\beta$ subunit of a calcium binding protein present mainly in glial and Schwann cells, ${ }^{18}$ increase in human blood and cerebrospinal fluid after a wide range of diseases or conditions leading to brain damage. ${ }^{19-28}$ Increased concentrations in blood and cerebrospinal fluid have been reported in patients with traumatic brain injury. ${ }^{29}$ Despite growing evidence suggesting a potential clinical role for S-100 $\beta$ as a biomarker, its association with short, mid, and long term prognosis remains unclear in patients with traumatic brain injury. There are also concerns that extracerebral injuries could contribute to increases in concentrations. Measurements of S-100 $\beta$ protein, or other biomarkers, are not widely used in clinical practice and are not considered standard of care. ${ }^{14}{ }^{15} \mathrm{We}$ therefore conducted a systematic review to evaluate the prognostic value of the $S-100 \beta$ protein after moderate or severe traumatic brain injury.

\section{Materials and methods Search strategy}

We searched Medline, Embase, Cochrane Central Register of Controlled Trials (Central), and BIOSIS from their inception to April 2012 for relevant studies. For Medline and Embase, we used validated combinations of terms for prognostic studies to achieve optimal search sensitivity and specificity. ${ }^{30}{ }^{31}$ Broad text and MeSH or EMTREE terms for biomarkers were used to maximise sensitivity. Our search strategy was designed to identify a wide range of biomarkers to increase sensitivity. The full search strategy for Medline is provided in appendix 1. We screened abstracts from relevant meetings (American Association of Neurological Surgeons, European Association of Neurosurgical Societies, Société de Neurochirurgie de Langue Française, Congress of Neurological Surgeons, Critical Care Canada Forum, International Trauma Anesthesia and Critical Care Society, World Federation of Societies of Intensive and Critical Care Medicine, Society of Critical Care Medicine, European Society of Intensive Care Medicine, International Symposium on Intensive Care Medicine, American association for the surgeons of trauma) and reference lists of selected articles and relevant narrative reviews.

\section{Study selection}

Search results were combined and duplicates were excluded with EndNote (version X5, Thomson Reuters, 2011). Two reviewers (EM and JFS or $\mathrm{AB}$ ) independently reviewed all citations and selected eligible studies. A third author (AFT) was consulted in case of disagreement.

We included cohort studies and randomised controlled trials that determined S-100 $\beta$ protein concentrations in patients with moderate and/or severe traumatic brain injury as defined by a Glasgow coma score $<13 .{ }^{32}$ Included studies had to report at least one outcome of interest (mortality, Glasgow outcome score, ${ }^{33}$ or brain stem death) and had to report $S-100 \beta$ protein concentrations in cerebrospinal fluid, venous blood, arterial blood, and/or urine. One quantitative measurement of S-100 $\beta$ protein in the emergency room or the intensive care unit, along with at least one follow-up outcome measure after discharge from intensive care, was also required for inclusion. Studies with one or no patient having a favourable or an unfavourable outcome were excluded as no standard deviation could be computed. We included prospective and retrospective outcome assessments and avoided language based study exclusions. We excluded studies limited exclusively to children $($ aged $<18)$ and studies in which less than half of included patients had moderate or severe traumatic brain injury, unless we could extract the data related to patients with moderate or severe traumatic brain injury.

\section{Data abstraction}

Two reviewers (EM and JFS or AB) independently collected data using a standardised data abstraction form. We abstracted information related to study design, patient characteristics (age, sex, severity of injury, blunt or penetrating injury, type of lesions, mechanism of injury, Marshall score for computed tomography, clinical pupillary reaction, hypotension, hypoxaemia, intracranial pressure, and mechanical ventilation), treatments (operative and pharmacological), laboratory aspects of S-100 $\beta$ protein testing (type of assay used, time period of sampling, and sampling type), and clinical outcomes (outcome type and timing of assessment). In instances of duplicate reporting, we used data from the study that included the largest number of patients or, when available, individual patient data from each study. We contacted authors for clarification on study sample or for missing data.

If multiple measurements of S-100 $\beta$ were carried out, we used the first measurement after the injury for analysis. If outcomes were assessed at multiple time points, we used the measurement furthest from injury for analysis. When the Glasgow outcome scale was dichotomised by the authors, we retained their definition of unfavourable outcome. When the entire spectrum of the Glasgow outcome score was provided, we defined an unfavourable outcome as a score $\leq 3$. 


\section{Methodological quality and risk of bias of included studies}

We developed a modified version of the QUADAS-2 assessment tool $^{34}$ (appendix 2) to evaluate the risk of bias in prognostic studies. We also used the criteria for reporting observational studies proposed in the STROBE statement ${ }^{35}$ to complete the methodological evaluation of the included studies (appendix $3)$.

\section{Statistical analysis}

The distribution of S-100 $\beta$ concentrations were right skewed and we therefore log transformed them to yield a normal distribution, assessed with Shapiro-Wilk and

Kolmogorov-Smirnov normality tests. A log normal distribution facilitated the analysis and presentation of outcomes between groups with geometric means ratios, for which the null value is one. ${ }^{36}$ Therefore, a ratio greater than one indicates that mean concentrations are higher in the group with an unfavourable prognosis compared with the group with a favourable prognosis. $^{36}$

Analyses were performed with random effects models. The presence of potential heterogeneity was assessed with the $\mathrm{I}^{2}$ statistic. ${ }^{37}$ Sensitivity analyses based on a priori hypotheses (time period of evaluation, sampling time, sampling type, severity of traumatic brain injury, isolated traumatic brain injury, biochemical technique, blinding of outcome assessment) were performed to investigate expected or measured heterogeneity. When individual patient data were available, we computed receiver operating characteristics curves for each study and used a bivariate random effects regression model ${ }^{38}$ to pool the sensitivity and specificity of intervals of $S-100 \beta$ threshold values for mortality and Glasgow outcome score. We also computed discrimination threshold values for $100 \%$ specificity for each of these studies.

In some studies, it was unclear whether the authors presented standard deviations or standard errors. In these cases, to prevent an incorrect rejection of the null hypothesis (type I error), we assumed the reported statistics to be standard errors. Analyses were conducted with Review Manager version 5.0 (Cochrane Collaboration, Copenhagen, Denmark) and SAS version 9.2 (SAS Institute, Cary, NC). For all tests and confidence intervals we used a two tailed type I error rate of 5\%. The reporting of this systematic review complies with the PRISMA statement. ${ }^{39}$ Publication bias was evaluated through visual inspection of funnel plots.

\section{Quality of the evidence}

The quality of the evidence for the three main outcomes was determined with the GRADE approach ${ }^{40}$ with the GRADEpro software (version 3.2 for Windows. Jan Brozek, Andrew Oxman, Holger Schünemann, 2008).

\section{Results}

\section{Study identification and selection}

Our search strategy retrieved 9228 citations after removal of duplicates. After screening and the application of our inclusion and exclusion criteria, we included 41 studies $^{41-81}$ published between 1987 and April 2012 (1862 patients) (fig $1 \Downarrow$ ). With the exception of one conference proceeding ${ }^{44}$ and one pilot study reported as a table in the final study publication, ${ }^{75}$ all included studies were published peer reviewed manuscripts.

\section{Study characteristics}

Thirty nine studies were observational cohort studies and two were randomised controlled trials ${ }^{68} 72$ (table $1 \Downarrow$ ). Three studies were published in languages other than English: Chinese, ${ }^{61}$ Japanese, ${ }^{65}$ and Czech. ${ }^{70}$ Each study evaluated between four and 149 patients with moderate and severe traumatic brain injury. Only one study reported including penetrating trauma, which represented $6.7 \%$ of its sample. ${ }^{53}$ The main outcome measures presented were the Glasgow outcome score (30 studies), mortality (18 studies), and brain stem death (two studies). Site of S-100 $\beta$ protein sampling was venous (31 studies), arterial (10 studies), or cerebrospinal fluid (five studies). Eighteen studies presented data from two or more samples at different time points after traumatic brain injury. Ten studies presented individual patient data. ${ }^{42} 45495153576673-75$ Individual data for three studies by the same group ${ }^{42} 4957$ were combined in the meta-analysis as they presented data from the same patients. All analyses were performed with serum (arterial or venous) $\mathrm{S}-100 \beta$ protein concentrations.

Fifteen of the 41 included studies could not be incorporated in the meta-analysis: nine presented the peak concentrations of serial samples of $S-100 \beta$ protein plasma or cerebrospinal fluid $^{43474850607172}$ or the mean value ${ }^{52} 79$; two did not report measures of dispersion ${ }^{44}{ }^{61}$; two presented data on four or five patients, with one patient having a favourable outcome in each case $^{4156}$; and one reported only the threshold value for a $100 \%$ specificity for unfavourable prognosis. ${ }^{55}$ Finally, two studies reported brain stem deaths, ${ }^{58} 79$ but one reported the mean value of serial samples, which precluded the application of meta-analysis for this specific outcome.

\section{Methodological quality of included studies}

Seventeen studies examined the risk of bias, six studies presented a flow diagram of participants, 14 studies adequately described their study population (including missing data and patients lost during follow-up), and 13 studies presented their funding sources. Figure 2 and appendix 3 present a more complete evaluation of the methodological quality and risk of bias $\Downarrow$.

\section{Outcome measures}

We observed significant positive associations between serum concentrations of S-100 $\beta$ protein and outcome. Increased concentrations correlated with increased mortality (12 studies: geometric mean ratio $2.55,95 \%$ confidence interval 2.02 to 3.21 ; I $\mathrm{I}^{2} 56 \%$; fig $3 \Downarrow$ ), a Glasgow outcome score $\leq 3$ (18 studies: $2.62,2.01$ to $3.42 ; \mathrm{I}^{2} 79 \%$; fig $4 \Downarrow$ ), and brain stem death (one study: $2.9,2.3$ to 3.5$)$. The results were consistent in all sensitivity analyses and were not influenced by the presence of associated traumatic injuries in other parts of the body (tables $2 \Downarrow$ and $3 \Downarrow$ ). In mortality subgroup analyses, heterogeneity was lowered according to testing method and timing of outcome assessment. In the studies that we excluded because of lack of information on measures of dispersion, ${ }^{44} 6180$ we observed a significant and consistently positive association between serum concentrations of S-100 $\beta$ protein and mortality. In eight studies excluded from the meta-analysis because they reported only the peak or the mean values over serial samples, authors reported a significant association $(\mathrm{P}<0.05)$ between serum concentrations and mortality, ${ }^{48} 72$ Glasgow outcome score $\leq 3,{ }^{43} 4748506071$ and brain stem death. ${ }^{79}$ Three studies reported a significant association between $S-100 \beta$ protein concentrations in cerebrospinal fluid and a Glasgow outcome score $\leq 3$. ${ }^{51}{ }^{59}{ }^{62} \mathrm{We}$ also analysed the data using the Taylor series method, ${ }^{82} 83$ and 
this did not substantially change the results (data available from authors). These analyses, however, yielded to a quasi-absence of statistical heterogeneity in all analyses.

\section{Discrimination threshold}

For mortality (six studies), serum threshold values of 2.5-3.0 $\mu \mathrm{g} / \mathrm{L}$ yielded a mean specificity of $91 \%$ ( $95 \%$ confidence interval $84 \%$ to $95 \%$ ) and a sensitivity of $39 \%$ ( $24 \%$ to $57 \%$ ), while concentrations $>3.0 \mu \mathrm{g} / \mathrm{L}$ yielded a mean specificity of $97 \%$ (95\% to $98 \%$ ) (see appendix 4). When we considered each study individually, the respective serum thresholds to attain $100 \%$ specificity for prognosis of death, meaning that all surviving patients are correctly identified by the test (no false positive overdetection of prognosis of death), ranged from $1.38 \mu \mathrm{g} / \mathrm{L}$ to $10.50 \mu \mathrm{g} / \mathrm{L}$, with an associated sensitivity ranging from $14 \%$ to $60 \%$ (fig $5 \Downarrow$ ).

Similarly, for unfavourable neurological prognosis (Glasgow outcome score $\leq 3$ ) (five studies), threshold values of $2.5 \mu \mathrm{g} / \mathrm{L}$ to 3.0 yielded a specificity of $94 \%$ (95\% confidence interval $85 \%$ to $98 \%$ ) and a sensitivity of $38 \%(15 \%$ to $67 \%)$ and values $>3.0 \mu \mathrm{g} / \mathrm{L}$ yielded a specificity of $96 \%$ (91\% to $98 \%$ ) (appendix 4). Again, when we considered each study individually, threshold values for $100 \%$ specificity for unfavourable neurological prognosis ranged from $2.16 \mu \mathrm{g} / \mathrm{L}$ to $14.0 \mu \mathrm{g} / \mathrm{L}$, with an associated sensitivity ranging from $9 \%$ to $50 \%$ (fig $6 \Downarrow$ ).

\section{Publication bias and quality of evidence}

Visual evaluation of funnel plots did not indicate any publication bias (see appendix 5). The quality of the evidence for mortality and for unfavourable neurological outcome (Glasgow outcome score $\leq 3$ ) was moderate (table $4 \Downarrow$ ).

\section{Discussion}

This meta-analysis identified a significant association between S-100 $\beta$ protein serum concentrations and short (less than three months), mid (three to six months) or long term (six months and above) prognosis in patients with moderate or severe traumatic brain injury. The concentrations were significantly correlated with unfavourable prognosis, as defined by mortality or Glasgow outcome score $\leq 3$, irrespective of concomitant traumatic injuries. Serum thresholds values ranging from 1.38 $\mu \mathrm{g} / \mathrm{L}$ to $10.5 \mu \mathrm{g} / \mathrm{L}$ and from $2.16 \mu \mathrm{g} / \mathrm{L}$ to $14.0 \mu \mathrm{g} / \mathrm{L}$ were associated with $100 \%$ specificity for mortality and a Glasgow outcome score $\leq 3$, respectively. Our findings are highly relevant to the care of critically ill patients with traumatic brain injury, especially as to help informed decision with respect to the determination of prognosis.

\section{Strengths and weakness of study}

There are limitations of our systematic review. Firstly, there was considerable heterogeneity for all outcomes of interest. Heterogeneity among studies that assessed mortality was explained by the testing method used and by the time period over which outcome was evaluated. Sensitivity analyses including the type of assay used, the timing of sampling, the sampling type, isolated versus multiple trauma, and the timing of outcome evaluation after traumatic brain injury, however, did not fully explain the observed heterogeneity for the Glasgow outcome score. Secondly, the use of the first measurement of $\mathrm{S}-100 \beta$ in our meta-analysis when more than one sample was collected could have generated more conservative estimates as samples obtained between 12 and 24 hours after admission showed a stronger association with outcome measures, which could reflect the impact of secondary neurological injuries like hypoxaemia, hypotension, and increased intracranial pressure. Thirdly, though we carried out our systematic review according to high methodological standards,$^{39}$ the results of the meta-analysis are limited by the quality of studies included. For example, only 16 studies reported outcome assessment that was blinded from S-100 $\beta$ protein concentrations, which implies a high risk of bias. Moreover, we cannot exclude potential publication bias.

Fourthly, we could not perform sensitivity analyses related to age, pupillary reactivity, or the motor component of the Glasgow coma score, which are known indicators of prognosis in such patients, because of the variable presentations or absence of these data in included studies. Finally, the different chemical assays used could have affected the accuracy and precision of the measured thresholds of S-100 $\beta$ protein concentrations. Although the sensitivity analyses did not show any major impact on the results, some of the assays were used in only a few studies, thus precluding a robust interpretation of their impact. Finally, the S-100 $\beta$ protein concentrations could potentially be affected by previous neurological disease ${ }^{84}$ or high serum alcohol concentrations. ${ }^{85}$ Data on those variables were rarely available and precluded any sensitivity analysis. While these variables could potentially have an impact in mild traumatic brain injury, however, this is unlikely to be considerable for moderate and severe injuries considering the importance of the traumatic brain injury.

Our systematic review had important strengths. We conducted a thorough systematic search, including different databases, and used a comprehensive analytical approach that allowed the inclusion of studies presenting not only means and standard deviations, but also centiles such as medians, thus improving the exhaustiveness of the results. Our rigorous methods were based on guidelines for conducting and reporting systematic reviews.

\section{Comparison with previous knowledge}

Previous narrative reviews published to date have outlined the potential of S-100 $\beta$ protein concentrations for predicting outcome after moderate or severe traumatic brain injury, but none of these used systematic review methods or incorporated meta-analyses. ${ }^{14} 151786-95$ The results of our study are consistent with those from two previous systematic reviews conducted in patients with stroke or cardiac arrest. ${ }^{96}{ }^{97}$ The first review found an association between $\mathrm{S}-100 \beta$ protein concentrations and prognostic features (infarct volume and stroke severity), ${ }^{97}$ while the second review showed that $S-100 \beta$ protein might be a better outcome predictor than the neurone specific enolase after cardiac arrest. ${ }^{96}$ Our results are also consistent with a large observational study performed in unselected neurocritically ill patients that found that $S-100 \beta$ was associated with neurological deterioration or complications. ${ }^{98}$

The presence of extracerebral sources of S-100 $\beta$ protein could lead to an overestimation of the severity of the brain lesion in the early phase after traumatic brain injury in patients with multiple injuries. ${ }^{169-102}$ Only four studies included in our meta-analysis ${ }^{62} 687081$ specified not enrolling patients with associated multiple trauma. The association between S-100 $\beta$ protein concentrations and prognosis, however, was consistent irrespective of other injuries. This result is concordant with the observations that $\mathrm{S}-100 \beta$ protein concentrations are more specific to the brain than to any other organ. Given that $80-90 \%$ of the total amount of S-100 $\beta$ is found in cerebral tissue, ${ }^{93}$ and that serum concentrations of S-100 $\beta$ protein have been correlated 
with the extent of brain damage in traumatic brain injury on computed tomography ${ }^{46}$ and in patients with ischaemic stroke, ${ }^{103}$ the attributable concentrations and influence of extracerebral sources of S-100 $\beta$ is thus likely to be minimal. ${ }^{100}$ One excluded study previously proposed such an approach, ${ }^{104}$ but we could not evaluate this hypothesis as no study that included isolated head trauma reported individual patient data. Furthermore, we could not explore potential confounding from severity of extracerebral injuries as data were not reported by outcome groups.

The discriminative capacity of the S-100 $\beta$ protein in the prediction of mortality and neurological outcome in patients with moderate and severe traumatic brain injury provides a glimpse at its potential usefulness as part of a shared decision making process. Indeed, medical teams and relatives faced with decisions about level of care are often left with little information on probabilistic expectations regarding the prognosis in these patients. The high specificity observed at thresholds over 2.5 $\mu \mathrm{g} / \mathrm{L}$ makes the $\mathrm{S}-100 \beta$ protein a candidate variable to include - in combination with other prognostic indicators such as data from the clinical examination, imaging, and electrophysiological tests-in a prognostic model to help in a shared decision making process. Such a model could better inform clinical teams and relatives on expected clinically important outcomes and optimise the provision of healthcare. On the other hand, the high sensitivity of the S-100 $\beta$ protein to rule out a clinically important brain injury could be useful to provide guidance for the decision whether to perform additional diagnostic assessment such as imaging in patients with traumatic brain injury. As part of a decision aid, the $\mathrm{S}-100 \beta$ protein concentration could serve to rule out important traumatic brain injury and avoid exposing patients to unnecessary radiation from imaging, allow better triage and use of resources, and thus be a potentially cost effective measure.

Many questions remain unanswered, such as the optimal biochemical method, timing of sampling, and prognostic threshold. Different assays and timing of sampling might call for different thresholds. With the current level of evidence, we cannot comment on the optimal parameters for prognostic evaluation. Further research is needed to explore combination of variables known to be associated with clinical outcomes of traumatic brain injuries to develop a prognostic model with a high discriminative capacity.

\section{Conclusion}

We observed a significant association between serum concentrations of S-100 $\beta$ protein and unfavourable prognosis as defined by mortality, Glasgow outcome score $\leq 3$, and brain stem death. The optimal discrimination threshold values for S-100 $\beta$ protein and the optimal sampling time remain uncertain as there were important variations between studies. The measure of S-100 $\beta$ protein concentrations could potentially play a role as part of a decision aid in the prognostic evaluation of patients with traumatic brain injury as well as to potentially rule out important traumatic brain injury. Further efforts should focus on standardising testing methods and further research on identifying optimal threshold values and sampling time for prognosis determination and on combining S-100 $\beta$ protein concentrations with other prognostic indicators to improve the accuracy of prognostic models and help guiding level of care decisions in a shared decision making process.

We thank Lucie Côté from the Library of the CHU de Québec, Hôpital de l'Enfant-Jésus, for her help with the retrieval of study publications and Marie-Joëlle Poitras-Pariseau, Information Specialist at the Library of the Université Laval, for her help in the design of the search strategy.

Contributors: E Mercier, F Lauzier, R Zarychanski, L Moore, PA Archambault, F Lamontagne, F Légaré, E Randell, F Rousseau, DA Fergusson and $\mathrm{AF}$ Turgeon contributed to the conception and design of the study. EM, J-FS, AB, and AFT determined eligibility of search results and extracted data from included studies. EM, J-FS, AB, and AFT performed and reviewed the analyses. EM, AB, and AFT drafted the manuscript. All authors participated to the interpretation of the data, the critical review of the manuscript for important intellectual content and approved the final version. EM and AFT are guarantors.

Funding: This work was funded by the Fonds de la Recherche du Québec - Santé (FRQ-S) (Traumatology Research Consortium, grant No 23698), the Canadian Anesthesia Research Foundation (CARF), the Foundation of the Association des Anesthésiologistes du Québec (AAQ Foundation) and the Regroupement en Soins Critiques of the FRQ-S Respiratory Health Network. EM was supported by a research training grant (MSc) from the FRQ-S during the conduction of the study (No 23819). AFT, FL, and PL are recipients of a research career award from the FRQ-S. AFT and FL are supported by the Traumatology Research Consortium of the FRQ-S. LM, LAM, and DAF are recipients of new investigator awards from the Canadian Institutes of Health Research (CIHR). RZ is a recipient of an RCT mentorship award from the CIHR. Funding agencies had no role in any part of conduct of the study or preparation of the manuscript.

Competing interests: All authors have completed the ICMJE uniform disclosure form at www.icmje.org/coi_disclosure.pdf (available on request from the corresponding author) and declare: no support from any organisation for the submitted work; no financial relationships with any organisations that might have an interest in the submitted work in the previous three years; no other relationships or activities that could appear to have influenced the submitted work.

Ethical approval: Not required.

Data sharing: No additional data available.

1 Perel P, Wasserberg J, Ravi RR, Shakur H, Edwards P, Roberts I. Prognosis following head injury: a survey of doctors from developing and developed countries. J Eval Clin Pract 2007;13:464-0005.

2 Turgeon AF, Lauzier F, Burns KEA, Meade MO, Scales DC, Zarychanski R, et al. Determination of neurological prognosis in adult patients with severe traumatic brain injury: a survey of Canadian intensivists, neurosurgeons and neurologists. Crit Care Med 2013 Feb 4, epub ahead of print.

3 Brain Trauma Foundation, American Association of Neurological Surgeons, Congress of Neurological Surgeons, Joint Section on Neurotrauma and Critical Care, AANS/CNS. Guidelines for the management of severe traumatic brain injury. $J$ Neurotrauma 2007;24(suppl 1):S91-5.

4 Menon DK. Unique challenges in clinical trials in traumatic brain injury. Crit Care Med 2009;37(1 suppl):S129-35.

5 Kraus JF, McArthur DL. Epidemiologic aspects of brain injury. Neurol Clin 1996;14:435-50.

6 Murray GD, Teasdale GM, Braakman R, Cohadon F, Dearden M, lannotti F, et al. The European Brain Injury Consortium survey of head injuries. Acta Neurochir (Wien) 1999;141:223-36.

7 Myburgh JA, Cooper DJ, Finfer SR, Venkatesh B, Jones D, Higgins A, et al. Epidemiology and 12-month outcomes from traumatic brain injury in Australia and New Zealand. $J$ Trauma 2008;64:854-62.

8 Thornhill S, Teasdale GM, Murray GD, McEwen J, Roy CW, Penny KI. Disability in young people and adults one year after head injury: prospective cohort study. BMJ 2000;320:1631-5.

9 Turgeon AF, Lauzier F, Simard JF, Scales DC, Burns KE, Moore L, et al. Mortality associated with withdrawal of life-sustaining therapy for patients with severe traumatic brain injury: a Canadian multicentre cohort study. CMAJ 2011;183:1581-8.

10 Murray GD, Butcher I, McHugh GS, Lu J, Mushkudiani NA, Maas Al, et al. Multivariable prognostic analysis in traumatic brain injury: results from the IMPACT study. J Neurotrauma 2007;24:329-37.

11 Perel P, Edwards P, Wentz R, Roberts I. Systematic review of prognostic models in traumatic brain injury. BMC Med Inform Decis Mak 2006;6:38.

12 Perel P, Arango M, Clayton T, Edwards P, Komolafe E, Poccock S, et al. Predicting outcome after traumatic brain injury: practical prognostic models based on large cohort of international patients. BMJ 2008;336:425-9.

13 Zitnay GA, Zitnay KM, Povlishock JT, Hall ED, Marion DW, Trudel T, et al. Traumatic brain injury research priorities: The Conemaugh international brain injury symposium. $J$ Neurotrauma 2008;25:1135-52.

14 Kovesdi E, Luckl J, Bukovics P, Farkas O, Pal J, Czeiter E, et al. Update on protein biomarkers in traumatic brain injury with emphasis on clinical use in adults and pediatrics. Acta Neurochir (Wien) 2010;152:1-17.

15 Kochanek PM, Berger RP, Bayir H, Wagner AK, Jenkins LW, Clark RSB. Biomarkers of primary and evolving damage in traumatic and ischemic brain injury: Diagnosis, prognosis, 


\section{What is already known on this topic}

Many indicators have been independently associated with prognosis after traumatic brain injury, but they are of limited clinical use when considered separately and current prognostic models do not have sufficient discriminative capacity to inform clinical decision making S- $100 \beta$ protein concentrations have been shown to increase in blood and cerebrospinal fluid after a wide range of diseases or conditions leading to brain damage

\section{What this study adds}

S-100ß protein serum concentrations correlate significantly with unfavourable prognosis in patients with moderate or severe traumatic brain injury, as defined by mortality, Glasgow outcome score $\leq 3$, or brain stem death, with or without concomitant traumatic injuries

The association between serum concentrations of $\mathrm{S}-100 \mathrm{\beta}$ protein and prognosis was observed at discharge from intensive care and at one, three, and six months.

Serum threshold values ranging from $1.38 \mu \mathrm{g} / \mathrm{L}$ to $10.50 \mu \mathrm{g} / \mathrm{L}$ and from $2.16 \mu \mathrm{g} / \mathrm{L}$ to $14.00 \mu \mathrm{g} / \mathrm{L}$ were associated with $100 \%$ specificity for mortality and a Glasgow outcome score $\leq 3$, respectively

probing mechanisms, and therapeutic decision making. Curr Opin Crit Care 2008;14:135-41.

16 Goncalves CA, Leite MC, Nardin P. Biological and methodological features of the measurement of $\mathrm{S} 100 \mathrm{~B}$, a putative marker of brain injury. Clin Biochem 2008:41:755-63.

17 Papa L, Robinson G, Oli M, Pineda J, Demery J, Brophy G, et al. Use of biomarkers for diagnosis and management of traumatic brain injury patients. Expert Opin Med Diagn 2008;2:937-45.

18 Zimmer DB, Cornwall EH, Landar A, Song W. The S100 protein family: history, function, and expression. Brain Res Bull 1995;37:417-29.

19 Sheng JG, Mrak RE, Rovnaghi CR, Kozlowska E, Van Eldik LJ, Griffin WST. Human brain S100beta and S100beta mRNA expression increases with age: Pathogenic implications for Alzheimer's disease. Neurobiol Aging 1996;17:359-63.

20 Kuzumi E, Vuylsteke A, Guo X, Menon DK, Shaaban Ali M, Vaughan RS, et al. Serum S100 protein a marker of cerebral damage during cardiac surgery. Br J Anaesth 2000;85:936-37.

21 Lara DR, Gama CS, Belmonte-De-Abreu P, Portela LVC, Goncalves CA, Fonseca M, et al. Increased serum $\mathrm{S} 100 \mathrm{~B}$ protein in schizophrenia: a study in medication-free patients. $J$ Psychiatr Res 2001;35:11-4

22 Pelinka LE, Bahrami S, Szalay L, Umar F, Redl H. Hemorrhagic shock induces an S 100 B increase associated with shock severity. Shock 2003;19:422-6.

23 Stalnacke BM, Tegner Y, Sojka P. Playing soccer increases serum concentrations of the biochemical markers of brain damage S-100B and neuron-specific enolase in elite players: a pilot study. Brain Inj 2004;18:899-909.

24 Vos MJ, Postma TJ, Martens F, Uitdehaag BM, Blankenstein MA, Vandertop WP, et al. Serum levels of S-100B protein and neuron-specific enolase in glioma patients: a pilot study. Anticancer Res 2004;24:2511-4.

25 Mussack T, Klauss V, Ruppert V, Gippner-Steppert C, Biberthaler P, Schiemann U, et al. Rapid measurement of S-100B serum protein levels by Elecsys $\mathrm{S} 100$ immunoassay in patients undergoing carotid artery stenting or endarterectomy. Clin Biochem 2006:39:349-56.

26 Shinozaki K, Oda S, Sadahiro T, Nakamura M, Abe R, Nakada Ta, et al. Serum S-100B is superior to neuron-specific enolase as an early prognostic biomarker for neurological outcome following cardiopulmonary resuscitation. Resuscitation 2009;80:870-5.

27 Teepker M, Munk K, Mylius V, Haag A, Moller JC, Oertel WH, et al. Serum concentrations of s100b and NSE in migraine. Headache 2009:49:245-52.

28 Yardan T, Cevik Y, Donderici O, Kavalci C, Yilmaz FM, Yilmaz G, et al. Elevated serum $\mathrm{S} 100 \mathrm{~B}$ protein and neuron-specific enolase levels in carbon monoxide poisoning. $\mathrm{Am} J$ Emerg Med 2009;27:838-42.

29 Petzold A, Keir G, Lim D, Smith M, Thompson EJ. Cerebrospinal fluid (CSF) and serum S100B: release and wash-out pattern. Brain Res Bull 2003;61:281-5.

30 Wilczynski NL, Haynes RB. Optimal search strategies for detecting clinically sound prognostic studies in EMBASE: An analytic survey. J Am Med Inform Assoc 2005;12:481-5

31 Wilczynski NL, Haynes RB, Eady A, Haynes B, Marks S, McKibbon A, et al. Developing optimal search strategies for detecting clinically sound prognostic studies in MEDLINE: an analytic survey. BMC Medicine 2004;2:23.

32 Teasdale G, Jennett B. Assessment of coma and impaired consciousness. A practica scale. Lancet 1974;ii:81-4.

33 Jennett B, Bond M. Assessment of outcome after severe brain damage. Lancet $1975 ;$;: $480-4$.

34 Whiting PF, Rutjes AW, Westwood ME, Mallett S, Deeks JJ, Reitsma JB, et al. QUADAS-2: a revised tool for the quality assessment of diagnostic accuracy studies. Ann Intern Med 2011;155:529-36

35 Von Elm E, Altman DG, Egger M, Pocock SJ, Gotzsche PC, Vandenbroucke JP. The Strengthening the Reporting of Observational Studies in Epidemiology (STROBE) statement: guidelines for reporting observational studies. Lancet 2007;370:1453-7

36 Bland JM, Altman DG. The use of transformation when comparing two means. BMJ 1996;312:1153.

37 Higgins JPT, Thompson SG, Deeks JJ, Altman DG. Measuring inconsistency in meta-analyses. BMJ 2003;327:557-60.

38 Reitsma JB, Glas AS, Rutjes AW, Scholten RJ, Bossuyt PM, Zwinderman AH. Bivariate analysis of sensitivity and specificity produces informative summary measures in diagnostic reviews. J Clin Epidemiol 2005;58:982-90.

39 Moher D, Liberati A, Tetzlaff J, Altman DG. Preferred reporting items for systematic reviews and meta-analyses: the PRISMA statement. BMJ 2009;339:b2535.

40 Atkins D, Best D, Briss PA, Eccles M, Falck-Ytter Y, Flottorp S, et al. Grading quality of evidence and strength of recommendations. BMJ 2004;328:1490.

41 Persson L, Hardemark HG, Gustafsson J, Rundstrom G, Mendel-Hartvig I, Esscher T, et al. S-100 protein and neuron-specific enolase in cerebrospinal fluid and serum: markers of cell damage in human central nervous system. Stroke 1987;18:911-8.

42 Woertgen C, Rothoerl RD, Holzschuh M, Metz C, Brawanski A. Comparison of serial S-100 and NSE serum measurements after severe head injury. Acta Neurochir (Wien) 1997;139:1161-5.
43 McKeating EG, Andrews PJ, Mascia L. Relationship of neuron specific enolase and protein S-100 concentrations in systemic and jugular venous serum to injury severity and outcome after traumatic brain injury. Acta Neurochir (Wien) 1998;71(suppl.):117-9.

44 Meissner W, Fritz H, Deufel T, Dohm B, Meier-Hellmann A, Reinhart K. S-100 protein: marker for severity of head injury? Crit Care Med 1998;26(1 suppl.):83A.

45 Raabe A, Menon DK, Gupta S, Czosnyka M, Pickard JD. Jugular venous and arterial concentrations of serum S-100B protein in patients with severe head injury: a pilot study. J Neurol Neurosurg Psychiatry 1998;65:930-2.

46 Raabe A, Grolms C, Keller M, Dohnert J, Sorge O, Seifert V. Correlation of computed tomography findings and serum brain damage markers following severe head injury. Acta Neurochir (Wien) 1998:140:787-92.

47 Raabe A, Grolms C, Seifert V. Serum markers of brain damage and outcome prediction in patients after severe head injury. Br J Anaesth 1999;13:56-9.

48 Raabe A, Grolms C, Sorge O, Zimmermann M, Seifert V. Serum S-100B protein in severe head injury. Neurosurgery 1999;45:477-83.

49 Woertgen C, Rothoerl RD, Metz C, Brawanski A. Comparison of clinical, radiologic, and serum marker as prognostic factors after severe head injury. J Trauma 1999:47:1126-30.

50 Elting JW, De Jager AEJ, Teelken AW, Schaaf MJ, Maurits NM, Van Der Naalt J, et al. Comparison of serum S-100 protein levels following stroke and traumatic brain injury. $J$ Neurol Sci 2000;181:104-10.

51 Jackson RG, Samra GS, Radcliffe J, Clark GH, Price CP. The early fall in levels of S-100 beta in traumatic brain injury. Clin Chem Lab Med 2000;38:1165-7.

52 Pleines UE, Morganti-Kossmann MC, Rancan M, Joller H, Trentz O, Kossmann T. $\mathrm{S}-100$ beta reflects the extent of injury and outcome, whereas neuronal specific enolase is a better indicator of neuroinflammation in patients with severe traumatic brain injury. $J$ Neurotrauma 2001;18:491-8.

53 Regner A, Kaufman M, Friedman G, Chemale I. Increased serum S100beta protein concentrations following severe head injury in humans: a biochemical marker of brain death? Neuroreport 2001;12691-4.

54 Chatfield DA, Zemlan FP, Day DJ, Menon DK. Discordant temporal patterns of s100beta and cleaved tau protein elevation after head injury: aA pilot study. Br J Anaesth 2002;16:471-6.

55 Mussack T, Biberthaler P, Kanz KG, Wiedemann E, Gippner-Steppert C, Mutschler W, et al. Serum S-100B and interleukin-8 as predictive markers for comparative neurologic outcome analysis of patients after cardiac arrest and severe traumatic brain injury. Crit Care Med 2002;30:2669-74

56 Townend WJ, Guy MJ, Pani MA, Martin B, Yates DW. Head injury outcome prediction in the emergency department: a role for protein S-100B? J Neurol Neurosurg Psychiatry 2002;73:542-6.

57 Woertgen C, Rothoerl RD, Brawanski A. Early S-100B serum level correlates to quality of life in patients after severe head injury. Brain Inj 2002:16:807-16.

58 Dimopoulou L, Korfias S, Dafni U, Anthi A, Psachoulia C, Jullien G, et al. Protein S-100b serum levels in trauma-induced brain death. Neurology 2003;60:947-51.

59 Pelinka LE, Kroepfl A, Leixnering M, Buchinger W, Raabe A, Redl H. GFAP versus S100B in serum after traumatic brain injury: relationship to brain damage and outcome. $J$ Neurotrauma 2004;21:1553-61.

60 Hayakata T, Shiozaki T, Tasaki O, Ikegawa H, Inoue Y, Toshiyuki F, et al. Changes in CSF S100B and cytokine concentrations in early-phase severe traumatic brain injury. Shock 2004;22:102-7.

61 Hu DL, Liu XH, Yu XL, Guo HM, Guo B, Shi Y, et al. Clinical significance of serum S-100B protein in severe cerebral injury. Zhongguo Wei Zhong Bing Ji Jiu Yi Xue 2004;16:221-2.

62 Li N, Shen JK, Zhao WG, Cai Y, Li YF, Zhan SK, S-100B and neuron specific enolase in outcome prediction of severe head injury. Chin J Traumatol 2004:7:156-8.

63 Ucar T, Baykal A, Akyuz M, Dosemeci L, Toptas B. Comparison of serum and cerebrospinal fluid protein $\mathrm{S}-100 \mathrm{~b}$ levels after severe head injury and their prognostic importance. $J$ Trauma 2004;57:95-8.

64 Vos PE, Lamers KJB, Hendriks JCM, Van Haaren M, Beems T, Zimmerman C, et al. Glial and neuronal proteins in serum predict outcome after severe traumatic brain injury. Neurology 2004;62:1303-10.

65 Sawauchi S, Taya K, Murakami S, Ishii T, Ohtsuka T, Kato N, et al. Serum S-100B protein and neuron-specific enolase after traumatic brain injury. Neurological Surgery 2005;33:1073-80

66 Da Rocha AB, Schneider RF, De Freitas GR, Andre C, Grivicich I, Zanoni C, et al. Role of serum $\mathrm{S} 100 \mathrm{~B}$ as a predictive marker of fatal outcome following isolated severe head injury or multitrauma in males. Clin Chem Lab Med 2006:44:1234-42.

67 Wang $X H$, Zhang XD. Evaluating the prognosis and degree of brain injury by combined S-100 protein and neuron specific enolase determination. Neural Regeneration Research 2006;1:649-52

68 Ghori KA, Harmon DC, Elashaal A, Butler M, Walsh F, O'Sullivan MG, et al. Effect of midazolam versus propofol sedation on markers of neurological injury and outcome after isolated severe head injury: a pilot study. Crit Care Resusc 2007:9:166-71.

69 Korfias S, Stranjalis G, Boviatsis E, Psachoulia C, Jullien G, Gregson B, et al. Serum $\mathrm{S}-100 \mathrm{~B}$ protein monitoring in patients with severe traumatic brain injury. Intensive Care Med 2007;33:255-60. 
70 Lavicka P, Pikner R, Kormunda S, Topolcan O, Bosman R, Chytra I, et al. Importance of the $\mathrm{S} 100 \mathrm{~B}$ protein assessment in patients with isolated brain injury. Ceska a Slovenska Neurologie a Neurochirurgie 2007;70:521-26.

71 Nylen K, Ost M, Csajbok LZ, Nilsson I, Hall C, Blennow K, et al. Serum levels of S100B, S100A1B and S100BB are all related to outcome after severe traumatic brain injury. Acta Neurochir (Wien) 2008;150:221-7.

72 Baker AJ, Rhind SG, Morrison LJ, Black S, Crnko NT, Shek PN, et al. Resuscitation with hypertonic saline-dextran reduces serum biomarker levels and correlates with outcome in severe traumatic brain injury patients. J Neurotrauma 2009;26:1227-40.

73 Olivecrona M, Rodling-Wahlstrom M, Naredi S, Koskinen LOD. S-100B and neuron specific enolase are poor outcome predictors in severe traumatic brain injury treated by an intracranial pressure targeted therapy. J Neurol Neurosurg Psychiatry 2009;80:1241-7.

74 Rainey T, Lesko M, Sacho R, Lecky F, Childs C. Predicting outcome after severe traumatic brain injury using the serum S100B biomarker: results using a single (24h) time-point. Resuscitation 2009;80:341-5.

75 Rainey T, Lesko M, Sacho R, Lecky F, Childs C. Predicting outcome after severe traumatic brain injury using the serum $\mathrm{S} 100 \mathrm{~B}$ biomarker: results using a single (24h) time-point (Pilot study). Resuscitation 2009;80:341-5.

76 Murillo-Cabezas F, Munoz-Sanchez MA, Rincon-Ferrari MD, Martin-Rodriguez JF, Amaya-Villar R, Garcia-Gomez S, et al. The prognostic value of the temporal course of S100beta protein in post-acute severe brain injury: A prospective and observational study. Brain Inj 2010;24:609-19.

77 Vos, Jacobs, Andriessen, Lamers, Borm, Beems, et al. GFAP and S100B are biomarkers of traumatic brain injury: an observational cohort study. Neurology 2010;75:1786-93.

78 Wiesmann M, Steinmeier E, Magerkurth O, Linn J, Gottmann D, Missler U. Outcome prediction in traumatic brain injury: comparison of neurological status, CT findings, and prediction in traumatic brain injury: comparison of neurological status,

79 Böhmer AE, Oses JP, Schmidt AP, Perón CS, Krebs CL, Oppitz PP, et al. Neuron-specific enolase, $\mathrm{S} 100 \mathrm{~B}$, and glial fibrillary acidic protein levels as outcome predictors in patients with severe traumatic brain injury. Neurosurgery 2011;68:1624-31.

80 Gonzalez-Mao MC, Reparaz-Andrade A, Del Campo-Perez V, Alvarez-Garcia E, Vara-Perez C, Andrade-Olivie MA. Model predicting survival/exitus after traumatic brain injury: biomarker S100B 24h. Clin Lab 2011;57:587-97.

81 Stein DM, Lindell AL, Murdock KR, Kufera JA, Menaker J, Bochicchio GV, et al. Use of serum biomarkers to predict cerebral hypoxia after severe traumatic brain injury. $J$ Neurotrauma 2012;29:1140-9.

82 Higgins JP, White IR, Anzures-Cabrera J. Meta-analysis of skewed data: combining results reported on log-transformed or raw scales. Stat Med 2008;27:6072-92.

83 Friedrich JO, Adhikari NK, Beyene J. Ratio of geometric means to analyze continuous outcomes in meta-analysis: comparison to mean differences and ratio of arithmetic means using empiric data and simulation. Stat Med 2012;31:1857-86

84 Steiner J, Bogerts B, Schroeter ML, Bernstein HG. S100B protein in neurodegenerative disorders. Clin Chem Lab Med 2011;49:409-24.

85 Lange RT, Brubacher JR, Iverson GL, Procyshyn RM, Mitrovic S. Differential effects of alcohol intoxication on $\mathrm{S} 100 \mathrm{~B}$ levels following traumatic brain injury. $J$ Trauma 2010;68:1065-71.

86 Raabe A, Kopetsch O, Woszczyk A, Lang J, Gerlach R, Zimmermann M, et al. Serum $\mathrm{S}-100 \mathrm{~B}$ protein as a molecular marker in severe traumatic brain injury. Restor Neurol Neurosci 2003;21:159-69.

87 Pelinka LE. Serum markers of severe traumatic brain injury: Are they useful? Indian $J$ Crit Care Med 2004;8:190-93.
88 Lomas JP, Dunning J. Best evidence topic report. S-100b protein levels as a predictor for long-term disability after head injury. Emerg Med J 2005;22:889-91.

89 Berger RP. The use of serum biomarkers to predict outcome after traumatic brain injury in adults and children. J Head Trauma Rehabil 2006;21:315-33.

90 Kleindienst A, Bullock MR. A critical analysis of the role of the neurotrophic protein S100B in acute brain injury. J Neurotrauma 2006;23:1185-200.

91 Stroick M, Fatar M, Ragoschke-Schumm A, Fassbender K, Bertsch T, Hennerici MG. Protein S-100B: A prognostic marker for cerebral damage. Curr Med Chem 2006;13:3053-60.

92 Townend W, Ingebrigtsen T. Head injury outcome prediction: a role for protein S-100B? Injury 2006;37:1098-108.

93 Sen J, Belli A. S100B in neuropathologic states: the CRP of the brain? J Neurosci Res 2007;85:1373-80.

94 Hergenroeder GW, Redell JB, Moore AN, Dash PK. Biomarkers in the clinical diagnosis and management of traumatic brain injury. Mol Diagn Ther 2008;12:345-58.

95 Yuan XS, Bian XX. S100B protein and its clinical effect on craniocerebral injury. Chin J Traumatol 2008;11:54-7.

96 Shinozaki K, Oda S, Sadahiro T, Nakamura M, Hirayama Y, Abe R, et al. S-100B and neuron-specific enolase as predictors of neurological outcome in patients after cardiac arrest and return of spontaneous circulation: a systematic review. Crit Care 2009:13:R121.

97 Nash DL, Bellolio MF, Stead LG. S100 as a marker of acute brain ischemia: a systematic review. Neurocrit Care 2008;8:301-7.

98 Raabe A, Kopetsch O, Woszczyk A, Lang J, Gerlach R, Zimmermann M, et al. S-100B protein as a serum marker of secondary neurological complications in neurocritical care patients. Neurol Res 2004;26:440-5.

99 Anderson RE, Hansson LO, Nilsson O, Liska J, Settergren G, Vaage J. Increase in serum S100A1-B and S100BB during cardiac surgery arises from extracerebral sources. Ann Thorac Surg 2001;71:1512-7.

100 Savola O, Pyhtinen J, Leino TK, Siitonen S, Niemela O, Hillbom M. Effects of head and extracranial injuries on serum protein $\mathrm{S} 100 \mathrm{~B}$ levels in trauma patients. $J$ Trauma 2004;56:1229-34.

101 Unden J, Bellner J, Eneroth M, Alling C, Ingebrigtsen T, Romner B. Raised serum S100B levels after acute bone fractures without cerebral injury. J Trauma 2005;58:59-61.

102 Routsi C, Stamataki E, Nanas S, Psachoulia C, Stathopoulos A, Koroneos A, et al. Increased levels of serum S100B protein in critically ill patients without brain injury. Shock 2006;26:20-4.

103 Ahmad O, Wardlaw J, Whiteley WN. Correlation of levels of neuronal and glial markers with radiological measures of infarct volume in ischaemic stroke: a systematic review. Cerebrovasc Dis 2012;33:47-54

104 Pelinka LE, Toegel E, Mauritz W, Redl H. Serum S 100 B: a marker of brain damage in traumatic brain injury with and without multiple trauma. Shock 2003;19:195-200.

Accepted: 12 February 2013

\section{Cite this as: BMJ 2013:346:f1757}

This is an Open Access article distributed in accordance with the Creative Commons Attribution Non Commercial (CC BY-NC 3.0) license, which permits others to distribute, remix, adapt, build upon this work non-commercially, and license their derivative works on different terms, provided the original work is properly cited and the use is non-commercial. See: http://creativecommons.org/licenses/by-nc/3.0/. 


\section{Tables} Table 1 Characteristics of studies included in review of role of S-100ß protein concentrations in prognosis in patients with moderate and
severe traumatic brain injury

\begin{tabular}{|c|c|c|c|c|c|c|c|}
\hline Studies & $\begin{array}{c}\text { No } \\
\text { patients }\end{array}$ & Inclusion criteria & Age (years) ${ }^{\star}$ & Female/male & Severity scales & Assay & Main outcome \\
\hline Persson et $\mathrm{al}^{41}$ & 4 & NR & NR & NR & NR & Custom & $\begin{array}{l}\text { GOS at hospital } \\
\text { discharge: } 1-3 \\
\text { unfavourable, } 4-5 \\
\text { favourable }\end{array}$ \\
\hline McKeating et al ${ }^{43}$ & 21 & $\begin{array}{l}\text { Traumatic brain injury, admitted to } \\
\text { ICU }\end{array}$ & $35(17-69)$ & $4 / 17$ & $\begin{array}{l}\text { Median (range) } \\
\text { GCS } 6(3-13), \text { ISS } \\
25(9-38)\end{array}$ & $\begin{array}{l}\text { RIA, DiaSorin } \\
\text { Diagnostica }\end{array}$ & $\begin{array}{l}\text { GOS at } 6 \text { months: } 1-3 \\
\text { unfavourable, } 4-5 \\
\text { favourable }\end{array}$ \\
\hline Meissner et al ${ }^{44}$ & 20 & NR & NR & NR & NR & NR & Mortality \\
\hline Raabe et $\mathrm{al}^{45}$ & 15 & $\begin{array}{l}\text { GCS } \leq 8 . \text { Retrograde jugular } \\
\text { venous catheter inserted }\end{array}$ & $39(17-61)$ & $5 / 10$ & $\begin{array}{l}\text { Median (range) } \\
\text { GCS } 5 \text { (3-8), } \\
\text { APACHE II } 15 \\
(14-17)\end{array}$ & $\begin{array}{l}\text { LIA, DiaSorin } \\
\text { Diagnostic }\end{array}$ & $\begin{array}{l}\text { GOS at } 6 \text { months: } 1-3 \\
\text { unfavourable, } 4-5 \\
\text { favourable }\end{array}$ \\
\hline Raabe et $\mathrm{al}^{46}$ & 44 & Severe head injury & $41(16-83)$ & $11 / 33$ & $\begin{array}{l}\text { Median (range) } \\
\text { GCS } 5(3-8)\end{array}$ & $\begin{array}{l}\text { RIA, DiaSorin } \\
\text { Diagnostica }\end{array}$ & $\begin{array}{l}\text { GOS at } 6 \text { months: } 1-3 \\
\text { unfavourable, } 4-5 \\
\text { favourable }\end{array}$ \\
\hline Raabe et $\mathrm{al}^{47}$ & 82 & $\begin{array}{l}\text { GCS } \leq 8 \text { after resuscitation. } \\
\text { Admitted to neurosurgical ICU }\end{array}$ & $38(16-85)$ & $16 / 66$ & NR & $\begin{array}{l}\text { RIA and LIA, } \\
\text { DiaSorin } \\
\text { Diagnostica }\end{array}$ & $\begin{array}{l}\text { GOS at } 6 \text { months: } 1-3 \\
\text { unfavourable, } 4-5 \\
\text { favourable }\end{array}$ \\
\hline Raabe et $\mathrm{al}^{48}$ & 84 & $\begin{array}{l}\text { GCS } \leq 8 \text { post-resuscitation } \\
\text { Closed TBI }\end{array}$ & $39(16-85)$ & $17 / 67$ & $\begin{array}{l}15(18 \%) \text { with } \\
\text { extracranial injuries }\end{array}$ & $\begin{array}{l}\text { RIA and LIA, } \\
\text { DiaSorin } \\
\text { Diagnostica }\end{array}$ & Mortality at 6 months \\
\hline Elting et $\mathrm{a}^{50}$ & 10 & $\begin{array}{l}\text { No epidural haematoma requiring } \\
\text { surgery. No previous head injury, } \\
\text { stroke or CNS infection within past } \\
3 \text { months }\end{array}$ & $\begin{array}{l}\text { Mean (SD) } 43 \\
(21)\end{array}$ & $4 / 6$ & $\begin{array}{l}\text { Mean (SD) GCS } \\
10.3(4.3), \text { range } \\
3-13\end{array}$ & $\begin{array}{l}\text { LIA, DiaSorin } \\
\text { Diagnostica }\end{array}$ & $\begin{array}{l}\text { GOS at } 6 \text { months: } 1-3 \\
\text { unfavourable, } 4-5 \\
\text { favorable }\end{array}$ \\
\hline Jackson et $\mathrm{al}^{51}$ & 30 & $\begin{array}{l}\text { History suggestive of severe } \\
\text { traumatic brain injury }\end{array}$ & NR & $20 / 10$ & NR & $\begin{array}{l}\text { LIA, DiaSorin } \\
\text { Diagnostica }\end{array}$ & $\begin{array}{l}\text { GOS at hospital discharge } \\
\text { and at } 6 \text { months: } 1-3 \\
\text { unfavourable, } 4-5 \\
\text { favourable }\end{array}$ \\
\hline Pleines et $\mathrm{al}^{52}$ & 13 & $\begin{array}{l}\text { GCS } \leq 8 \text { admission. Isolated } \\
\text { traumatic brain injury }\end{array}$ & $\begin{array}{l}\text { Mean (range) } \\
36(16-67)\end{array}$ & NR & NR & $\begin{array}{l}\text { ELISA, DiaSorin } \\
\text { Diagnostica }\end{array}$ & $\begin{array}{l}\text { GOS between } 3 \text { and } 6 \\
\text { months }\end{array}$ \\
\hline Regner et al ${ }^{53}$ & 15 & $\begin{array}{l}\text { Clinical condition equivalent to } \\
\text { GCS } \leq 8 \text { at admission and } 12 \text { and } \\
48 \mathrm{~h} \text {. Signs of intracranial lesions } \\
\text { on computed tomography. } \\
\text { Admitted to trauma ICU }\end{array}$ & $\begin{array}{l}\text { Mean (range) } \\
33(18-50)\end{array}$ & $2 / 13$ & Mean GCS 5 & $\begin{array}{l}\text { RIA, DiaSorin } \\
\text { Diagnostica }\end{array}$ & Mortality at ICU discharge \\
\hline Chatfield et $\mathrm{al}^{54}$ & 20 & $\begin{array}{l}\text { Traumatic brain injury. Admission } \\
\text { into neurosciences ICU required }\end{array}$ & $\begin{array}{l}\text { Mean (SD) } 29 \\
(15), \text { range } \\
16-60\end{array}$ & NR & $\begin{array}{l}\text { Median (range) } \\
\text { GCS } 6 \text { (3-9), } \\
\text { APACHE II } 14 \\
(7-19), \text { ISS } 25 \\
(9-50)\end{array}$ & $\begin{array}{l}\text { LIA, DiaSorin } \\
\text { Diagnostica }\end{array}$ & $\begin{array}{l}\text { GOS at } 6 \text { months: } 1-3 \\
\text { unfavourable, } 4-5 \\
\text { favourable }\end{array}$ \\
\hline Mussack et al. ${ }^{55}$ & 20 & $\begin{array}{l}\text { GCS } \leq 8 \text { on admission. Isolated } \\
\text { traumatic brain injury. No traumatic } \\
\text { circulatory arrest. Surviving at least } \\
12 \mathrm{~h} \text { after admission }\end{array}$ & $\begin{array}{l}\text { Mean }(95 \% \mathrm{Cl}) \\
45(24.1 \text { to } \\
81.9)\end{array}$ & $4 / 16$ & NR & $\begin{array}{l}\text { LIA, DiaSorin } \\
\text { Diagnostica }\end{array}$ & $\begin{array}{l}\text { GOS at } 12 \text { months: } 1-3 \\
\text { unfavourable, } 4-5 \\
\text { favourable }\end{array}$ \\
\hline Townend et $\mathrm{al}^{56}$ & 5 & $\begin{array}{l}\text { Traumatic brain injury and } \\
\text { presentation to emergency } \\
\text { department within } 6 \mathrm{~h} \text { after injury }\end{array}$ & $\begin{array}{l}\text { Mean (range) } \\
47.4(18-94)\end{array}$ & $50 / 93$ & $\begin{array}{l}130 \text { with GCS } 15,5 \\
\text { with GCS } \leq 8\end{array}$ & $\begin{array}{l}\text { LIA, DiaSorin } \\
\text { Diagnostica }\end{array}$ & GOSE at 1 month \\
\hline $\begin{array}{l}\text { Woertgen et al }{ }^{42} \\
4957\end{array}$ & 54 & $\begin{array}{l}\text { GCS } \leq 8 \text {. Admitted between 1-6 h } \\
\text { after injury. No spinal cord injury. } \\
\text { No history of neurological disease. } \\
\text { No resuscitation or shock }\end{array}$ & $\begin{array}{l}\text { Mean (range) } \\
34.5(16-79)\end{array}$ & $15 / 42$ & NR & $\begin{array}{l}\text { RIA, DiaSorin } \\
\text { Diagnostica }\end{array}$ & $\begin{array}{l}\text { Mortality and GOS at } 12 \\
\text { months: } 1-3 \text { unfavourable, } \\
4-5 \text { favourable }\end{array}$ \\
\hline $\begin{array}{l}\text { Dimopoulou et } \\
\mathrm{a}^{58}\end{array}$ & 47 & $\begin{array}{l}\text { GCS } \leq 8 \text {. Admitted to ICU. No brain } \\
\text { stem death at admission }\end{array}$ & $34(17-75)$ & $6 / 41$ & $\begin{array}{l}\text { Median (range) } \\
\text { GCS } 6(3-8)\end{array}$ & $\begin{array}{l}\text { LIA, DiaSorin } \\
\text { Diagnostica }\end{array}$ & $\begin{array}{l}\text { Brain stem death at } 6 \\
\text { days }\end{array}$ \\
\hline Pelinka et al ${ }^{59}$ & 92 & $\begin{array}{l}\text { Traumatic brain injury with or } \\
\text { without multiple trauma }<12 \mathrm{~h} \text { after } \\
\text { admission. }\end{array}$ & $\begin{array}{l}\text { Median (IQR) } \\
39(28-55)\end{array}$ & $25 / 67$ & $\begin{array}{l}\text { Median (IQR) GCS } \\
6(3-8), \text { ISS } 25 \\
(18-34)\end{array}$ & $\begin{array}{l}\text { LIA, DiaSorin } \\
\text { Diagnostica }\end{array}$ & $\begin{array}{l}\text { Mortality and GOS at } 3 \\
\text { months }\end{array}$ \\
\hline
\end{tabular}


Table 1 (continued)

\begin{tabular}{|c|c|c|c|c|c|c|c|}
\hline Studies & $\begin{array}{c}\text { No } \\
\text { patients }\end{array}$ & Inclusion criteria & Age (years) ${ }^{*}$ & Female/male & Severity scales & Assay & Main outcome \\
\hline Hayakata et al ${ }^{60}$ & 23 & $\begin{array}{l}\text { GCS } \leq 8 \text {. Age }>9 \text {. No severe life } \\
\text { threatening injury to vital organs } \\
\text { other than brain }\end{array}$ & $\begin{array}{l}\text { Mean (range) } \\
40(14-68)\end{array}$ & $6 / 17$ & NR & $\begin{array}{l}\text { RIA, DiaSorin } \\
\text { Diagnostica }\end{array}$ & $\begin{array}{l}\text { GOS at } 6 \text { months: } 1-3 \\
\text { unfavourable, } 4-5 \\
\text { favourable }\end{array}$ \\
\hline Hu et $\mathrm{al}^{61}$ & 66 & $\mathrm{GCS} \leq 8$ & $\begin{array}{l}\text { Mean (range) } \\
37.5(16-75)\end{array}$ & $14 / 52$ & $\begin{array}{l}\text { Mean (range) GCS } \\
5(3-8)\end{array}$ & $\begin{array}{l}\text { ELISA, Roche } \\
\text { Diagnostica }\end{array}$ & Mortality at 6 months \\
\hline Li et al ${ }^{62}$ & 40 & $\begin{array}{l}\text { GCS } \leq 8 \text {. No severe systemic } \\
\text { injury. No heart or renal failure. No } \\
\text { severe infection of central nervous } \\
\text { system }\end{array}$ & NR & NR & NR & $\begin{array}{l}\text { LIA, DiaSorin } \\
\text { Diagnostica }\end{array}$ & $\begin{array}{l}\text { GOS at } 6 \text { months: } 1-3 \\
\text { unfavourable, } 4-5 \\
\text { favourable }\end{array}$ \\
\hline Ucar et $\mathrm{al}^{63}$ & 48 & $\begin{array}{l}\text { GCS } \leq 8 \text {. Admitted to emergency } \\
\text { department soon after traumatic } \\
\text { brain injury }\end{array}$ & NR & $15 / 33$ & NR & $\begin{array}{l}\text { RIA, DiaSorin } \\
\text { Diagnostica }\end{array}$ & $\begin{array}{l}\text { GOS at } 6-9 \text { months after } \\
\text { hospital discharge: } 1-3 \\
\text { unfavourable, } 4-5 \\
\text { favourable }\end{array}$ \\
\hline Vos et $a^{64}$ & 84 & $\begin{array}{l}\text { GCS } \leq 8 \text { after resuscitation. } \\
\text { Admitted within } 36 \mathrm{~h} \text { after injury. } \\
\text { Closed head injury. Blood sample } \\
\text { taken. Informed consent. Possibility } \\
\text { of long term follow-up }\end{array}$ & $32(15-81)$ & $24 / 61$ & $\begin{array}{l}\text { Median (range) } \\
\text { GCS } 4 \text { (3-8), ISS } 29 \\
(9-75)\end{array}$ & $\begin{array}{l}\text { LIA, DiaSorin } \\
\text { Diagnostica }\end{array}$ & Mortality at 6 months \\
\hline Sawauchi et al ${ }^{65}$ & 41 & Consecutive traumatic brain injury & NR & NR & $\begin{array}{l}30 \text { with GCS }>8,11 \\
\text { with GCS } \leq 9\end{array}$ & NR & $\begin{array}{l}\text { GOS at } 3 \text { months: } 1-3 \\
\text { unfavourable, } 4-5 \\
\text { favourable }\end{array}$ \\
\hline daRocha et al ${ }^{66}$ & 23 & $\begin{array}{l}\text { GCS } \leq 8 \text { at emergency admission. } \\
\text { Age } 18-65 \text {. No history of } \\
\text { neurological or psychiatric disorder. } \\
\text { Transferred to ICU } \leq 24 \mathrm{~h} \text { after } \\
\text { traumatic brain injury. Male }\end{array}$ & $34(19-64)$ & $0 / 23$ & $\begin{array}{l}\text { Mean (SD) GCS } 6.0 \\
\text { (2.5), APACHE II } \\
16.9(6.2)\end{array}$ & $\begin{array}{l}\text { LIA, DiaSorin } \\
\text { Diagnostica }\end{array}$ & Mortality at ICU discharge \\
\hline Wang et $a^{67}$ & 34 & $\begin{array}{l}\text { Admitted to department of } \\
\text { neurosurgery }<24 \mathrm{~h} \text { after injury }\end{array}$ & Range $15-73$ & $15 / 19$ & NR & ECLIA & $\begin{array}{l}\text { GOS at } 3 \text { months: } 1-3 \\
\text { unfavourable, } 4-5 \\
\text { favourable }\end{array}$ \\
\hline Ghori et $\mathrm{al}^{68}$ & 28 & $\begin{array}{l}\text { GCS } \leq 8 \text {. Age } 18-65 \text {. Isolated head } \\
\text { injury. Requirement for mechanical } \\
\text { ventilation. No previous organic } \\
\text { brain disease or brain surgery or } \\
\text { spinal cord injury. No renal or } \\
\text { hepatic failure. BMI } \leq 32 \text {. No } \\
\text { pregnancy. No substance abuse } \\
\text { at ICU admission }\end{array}$ & NR & $1 / 27$ & $\begin{array}{l}\text { Median (range) } \\
\text { GCS 4,73 (3-7) with } \\
\text { midazolam, } 5.07 \\
\text { (3-7) with propofol }\end{array}$ & $\begin{array}{l}\text { RIA, DiaSorin } \\
\text { Diagnostica }\end{array}$ & $\begin{array}{l}\text { GOS at } 3 \text { months: } 1-3 \\
\text { unfavourable, } 4-5 \\
\text { favourable }\end{array}$ \\
\hline Korfias et al ${ }^{69}$ & 102 & $\begin{array}{l}\text { GCS } \leq 8 \text { at admission. Age }>14 \text {. } \\
\text { Admitted to neurological ICU }\end{array}$ & $35(16-86)$ & $21 / 81$ & $\begin{array}{l}\text { GCS: } 36 \text { with score } \\
3-4 ; 24 \text { with score } \\
5-6 ; 42 \text { with score } \\
7-8\end{array}$ & $\begin{array}{l}\text { LIA, DiaSorin } \\
\text { Diagnostica }\end{array}$ & Mortality at 1 month \\
\hline Lavicka et $\mathrm{al}^{70}$ & 98 & $\begin{array}{l}\text { Isolated traumatic brain injury } \\
\text { admitted }\end{array}$ & NR & NR & GCS & $\begin{array}{l}\text { LIA, DiaSorin } \\
\text { Diagnostica }\end{array}$ & $\begin{array}{l}\text { GOS at hospital } \\
\text { discharge: } 1-3 \\
\text { unfavourable, } 4-5 \\
\text { favourable }\end{array}$ \\
\hline Nylen et $\mathrm{al}^{71}$ & 59 & $\begin{array}{l}\text { GCS } \leq 8 \text { admitted to neurosurgical } \\
\text { ICU. Therapeutic indication for } \\
\text { monitoring ICP. Therapeutic } \\
\text { indication for ventilator treatment. } \\
\text { Start of sampling on day } 2 \text { at latest. } \\
\text { No life threatening trauma to other } \\
\text { organs }\end{array}$ & $37(8-81)$ & $15 / 44$ & NR & $\begin{array}{l}\text { ELISA, Fujirebio } \\
\text { Diagnostics }\end{array}$ & $\begin{array}{l}\text { GOS at } 12 \text { months: } 1-3 \\
\text { unfavourable, } 4-5 \\
\text { favourable }\end{array}$ \\
\hline Baker et $\mathrm{al}^{72}$ & 64 & $\begin{array}{l}\text { GCS } \leq 8 \text {. Coma or loss of } \\
\text { consciousness from isolated blunt } \\
\text { traumatic brain injury }\end{array}$ & $\begin{array}{l}\text { Mean (range) } \\
41.4 \\
(18.3-87.9)\end{array}$ & $23 / 41$ & $\begin{array}{l}\text { Mean (SD) GCS } 5.7 \\
(2.7)\end{array}$ & ELISA, Nexus DX & $\begin{array}{l}\text { Mortality and GOS at } \\
\text { hospital discharge (or } 30 \\
\text { days): } 1-3 \text { unfavourable, } \\
4-5 \text { favourable }\end{array}$ \\
\hline Olivecrona et $\mathrm{al}^{73}$ & 48 & $\begin{array}{l}\text { GCS } \leq 8 \text {. Age } 15-70 \text {. First recorded } \\
\mathrm{CPP}>10 \mathrm{~mm} \mathrm{Hg} \text {. Arrival }<24 \mathrm{~h} \\
\text { after traumatic brain injury }\end{array}$ & $31(15-63)$ & $17 / 31$ & $\begin{array}{l}\text { Median (range) ISS } \\
29(9-50), \text { APACHE } \\
\text { II } 21 \text { (12-32) }\end{array}$ & $\begin{array}{l}\text { LIA, DiaSorin } \\
\text { Diagnostica }\end{array}$ & $\begin{array}{l}\text { Mortality and GOS at } 3 \\
\text { and } 12 \text { months: } 1 \\
\text { deceased, 2-3 } \\
\text { unfavourable, 4-5 } \\
\text { favourable }\end{array}$ \\
\hline
\end{tabular}


Table 1 (continued)

\begin{tabular}{|c|c|c|c|c|c|c|c|}
\hline Studies & $\begin{array}{c}\text { No } \\
\text { patients }\end{array}$ & Inclusion criteria & Age (years) ${ }^{\star}$ & Female/male & Severity scales & Assay & Main outcome \\
\hline Rainey et $\mathrm{al}^{74}$ & 100 & $\begin{array}{l}\text { GCS } \leq 8 . \text { Age }>15 . \text { Admitted to ICU } \\
<24 \mathrm{~h} \text { after traumatic brain injury }\end{array}$ & $31(16-86)$ & $19 / 81$ & $\begin{array}{l}\text { Median (range) ISS } \\
25(9-50) \text {, multiple } \\
\text { trauma } 47 \%\end{array}$ & $\begin{array}{l}\text { ELISA, DiaSorin } \\
\text { Diagnostica }\end{array}$ & $\begin{array}{l}\text { Mortality and GOS at } 3 \\
\text { months: } 1-3 \text { unfavourable, } \\
4-5 \text { favourable }\end{array}$ \\
\hline $\begin{array}{l}\text { Rainey-pilot } \\
\text { study }\end{array}$ & 9 & $\mathrm{GCS} \leq 8$ & NR & NR & NR & $\begin{array}{l}\text { ELISA, DiaSorin } \\
\text { Diagnostica }\end{array}$ & Mortality \\
\hline $\begin{array}{l}\text { Murillo-Cabezas } \\
\text { et al }{ }^{76}\end{array}$ & 87 & $\begin{array}{l}\text { GCS } \leq 8 \text {. Age }>14 \text {. Serum sampling } \\
\leq 24 \text { hours after traumatic brain } \\
\text { injury. Haemodynamically stable }\end{array}$ & $30(15.0-76.0)$ & $14 / 73$ & $\begin{array}{l}\text { GCS at admission: } \\
20 \text { with score } 3-4 ; \\
23 \text { with score } 5-6 ; \\
44 \text { with score } 7-8\end{array}$ & ECLIA, Elecsys & $\begin{array}{l}\text { Mortality and GOS at } 12 \\
\text { months: } 1-3 \text { unfavourable, } \\
4-5 \text { favourable }\end{array}$ \\
\hline Vos et $\mathrm{al}^{77}$ & 79 & $\begin{array}{l}\text { GCS } \leq 13 \text {. Age }>17 \text {. Hospital } \\
\text { admission } \leq 24 \text { hours after } \\
\text { traumatic brain injury }\end{array}$ & $\begin{array}{c}47.0 \\
(18.0-91.0)\end{array}$ & $22 / 57$ & $\begin{array}{l}\text { Median (range) } \\
\text { GCS } 3 \text { (3-12) }\end{array}$ & $\begin{array}{l}\text { LIA, IntraOperative } \\
\text { platform, Future } \\
\text { Diagnostics }\end{array}$ & $\begin{array}{l}\text { Mortality and GOSE at } 6 \\
\text { months: } 1 \text { deceased, } 1-4 \\
\text { unfavourable, 5-8 } \\
\text { favourable }\end{array}$ \\
\hline Weismann et al ${ }^{78}$ & 60 & $\begin{array}{l}\text { Admitted }<24 \mathrm{~h} \text { after traumatic } \\
\text { brain injury. No known neurological } \\
\text { disease. No spinal cord injury }\end{array}$ & $\begin{array}{l}\text { Mean (SD) } 44 \\
(21)\end{array}$ & $15 / 45$ & $\begin{array}{l}\text { Mean (SD) GCS } 8 \\
\text { (4) }\end{array}$ & NR & $\begin{array}{l}\text { GOS at } 6 \text { months: } 1-3 \\
\text { unfavourable, } 4-5 \\
\text { favourable }\end{array}$ \\
\hline Böhmer et al $\mathrm{al}^{79}$ & 20 & $\begin{array}{l}\text { GCS } \leq 8 \text { with abnormal result on } \\
\text { computed tomography on } \\
\text { admission }\end{array}$ & $\begin{array}{l}\text { Mean (SD) } 29 \\
\text { (13) }\end{array}$ & $2 / 18$ & NR & $\begin{array}{l}\text { ELISA, DiaSorin } \\
\text { Diagnostica }\end{array}$ & Brain stem death \\
\hline $\begin{array}{l}\text { Gonzalez-Mao } \\
\text { et al }{ }^{80}\end{array}$ & 149 & $\begin{array}{l}\text { Admission within } 6 \mathrm{~h} \text { of injury. Main } \\
\text { diagnosis of traumatic brain injury. } \\
\text { Evaluation of history of psychiatric } \\
\text { and neurological disease. } \\
\text { Computed tomography within } 24 \mathrm{~h} \\
\text { of lesion }\end{array}$ & $\begin{array}{l}\text { Mean }(95 \% \mathrm{Cl}) \\
42.85(39.5 \text { to } \\
46.1) \text {, range } \\
15-84\end{array}$ & $30 / 119$ & $\begin{array}{l}\text { Mean GCS } 9.3 .77 \\
\text { with score }<9 ; 32 \\
\text { with score } 9-13 ; 40 \\
\text { with score } 14-15\end{array}$ & $\begin{array}{l}\text { LIA, DiaSorin } \\
\text { Diagnostica }\end{array}$ & $\begin{array}{l}\text { Mortality at hospital } \\
\text { discharge }\end{array}$ \\
\hline Stein et $a^{81}$ & 24 & $\begin{array}{l}\text { Age }>17 \text {. Admission within first } 6 \\
\mathrm{~h} \text { after injury. GCS score }<9 \text { on } \\
\text { admission. Placement of clinically } \\
\text { indicated ICP monitor }\end{array}$ & $\begin{array}{l}\text { Mean }(\mathrm{SD}) \\
30.7(12.3) \\
\text { range } 19-64\end{array}$ & $3 / 21$ & $\begin{array}{l}\text { Mean admission } \\
\text { (SD) GCS } 5.8 \text { (3.4) }\end{array}$ & $\begin{array}{l}\text { ELISA, Biovendor } \\
\text { Candor }\end{array}$ & $\begin{array}{l}\text { GOSE at } 3 \text { months, } 6 \\
\text { months and } 1 \text { year: } 1-4 \\
\text { unfavourable, } 5-8 \\
\text { favourable }\end{array}$ \\
\hline
\end{tabular}

APACHE II=acute physiology and chronic health evaluation II; CPP=cerebral perfusion pressure; ECLIA=electrochemiluminescence immunoassay; ELISA=enzyme linked immunosorbant assay; GCS=Glasgow coma scale; GOS=Glasgow outcome scale; GOSE=extended Glasgow outcome scale; ICP=intracranial pressure; $I C U=$ intensive care unit; IQR=interquartile range; ISS=injury severity score; $L I A=$ luminescence immunoassay; $N R=$ not reported; $R I A=$ radioimmunoassay.

*Median (range) unless stated otherwise. 
Table 2/ Sensitivity analyses for association of S-100 $\beta$ protein concentrations with mortality in patients with traumatic brain injury. Figures are geometric mean ratios ( $95 \%$ confidence interval)

\begin{tabular}{|c|c|c|c|}
\hline & No of studies & GMR $(95 \%$ CI) & $\left.\right|^{2}(\%)$ \\
\hline \multicolumn{4}{|l|}{ Evaluation time: } \\
\hline Intensive care unit & 1 & 2.83 (1.38 to 5.81$)$ & - \\
\hline Hospital & 1 & 3.82 (2.39 to 6.05$)$ & 一 \\
\hline 1 month & 1 & 2.01 (1.20 to 3.35$)$ & - \\
\hline 3 months & 4 & 2.64 (1.97 to 3.49 ) & 0 \\
\hline 6 months & 3 & 2.25 (1.63 to 3.13 ) & 0 \\
\hline 12 months & 2 & 2.46 (0.79 to 7.77$)$ & 94 \\
\hline \multicolumn{4}{|l|}{ Sampling time (hours): } \\
\hline$<12$ & 9 & 2.59 (1.92 to 3.49$)$ & 68 \\
\hline$<24$ & 16 & 2.75 (2.27 to 3.29 ) & 56 \\
\hline 48 & 4 & $4.10(3.03$ to 5.47$)$ & 28 \\
\hline 72 & 4 & 3.03 (2.36 to 3.86$)$ & 0 \\
\hline \multicolumn{4}{|l|}{ Sample type: } \\
\hline Arterial & 2 & 2.44 (1.73 to 3.46$)$ & 0 \\
\hline Venous & 10 & 2.59 (1.95 to 3.42 ) & 64 \\
\hline \multicolumn{4}{|l|}{ Biochemical method: } \\
\hline RIA & 2 & 3.94 (2.53 to 6.05$)$ & 11 \\
\hline LIA & 7 & 2.61 (2.12 to 3.22 ) & 0 \\
\hline ELISA & 2 & 2.44 (1.73 to 3.46$)$ & 0 \\
\hline ECLIA & 1 & $1.39(1.03$ to 1.90$)$ & - \\
\hline Other & 0 & - & \\
\hline \multicolumn{4}{|c|}{ Minimal severity of traumatic brain injury: } \\
\hline Mild & 2 & $3.49(2.41$ to 5.10$)$ & - \\
\hline Moderate & 1 & 2.08 (1.34 to 3.22$)$ & - \\
\hline Severe & 9 & 2.46 (1.84 to 3.25$)$ & 60 \\
\hline \multicolumn{4}{|l|}{ Isolated traumatic brain injury: } \\
\hline Isolated & 0 & - & - \\
\hline Multiple trauma or unspecified & 12 & $2.53(2.01$ to 3.19$)$ & 56 \\
\hline \multicolumn{4}{|l|}{ Blinding: } \\
\hline Blinded & 6 & 2.03 (1.57 to 2.66$)$ & 39 \\
\hline Unspecified & 6 & 3.16 (2.53 to 3.94$)$ & 4 \\
\hline
\end{tabular}

$E C L I A=$ =electrochemiluminescence immunoassay; ELISA=enzyme linked immunosorbent assay; $L I A=$ enzyme linked immunoluminometric assay; $R I A=$ immunoradiometric assay; TBI: traumatic brain injury. 
Table 3| Sensitivity analyses for association of S-100 $\beta$ protein concentrations with Glasgow outcome score $\leq 3$ in patients with traumatic brain injury. Figures are geometric mean ratios $(95 \%$ confidence interval)

\begin{tabular}{|c|c|c|c|}
\hline & No of studies & GMR (95\% Cl) & $\mathrm{I}^{2}(\%)$ \\
\hline \multicolumn{4}{|l|}{ Evaluation time (months): } \\
\hline 3 & 5 & 2.92 (1.41 to 6.06$)$ & 89 \\
\hline 6 & 10 & 2.53 (2.00 to 3.19 ) & 48 \\
\hline 12 & 3 & 2.74 (1.01 to 7.44$)$ & 90 \\
\hline \multicolumn{4}{|l|}{ Sampling time (hours): } \\
\hline$<12$ & 14 & 2.52 (1.89 to 3.36$)$ & 81 \\
\hline$<24$ & 24 & 2.65 (2.16 to 3.26$)$ & 78 \\
\hline 48 & 5 & 2.37 (1.51 to 3.73 ) & 67 \\
\hline 72 & 7 & 2.68 (1.58 to 4.56$)$ & 82 \\
\hline \multicolumn{4}{|l|}{ Sample type: } \\
\hline Arterial & 4 & 2.99 (2.09 to 4.30$)$ & 54 \\
\hline Venous & 13 & 2.43 (1.73 to 3.40$)$ & 82 \\
\hline \multicolumn{4}{|l|}{ Biochemical method: } \\
\hline RIA & 5 & 2.20 (1.45 to 3.32 ) & 61 \\
\hline LIA & 7 & 2.42 (1.72 to 3.40$)$ & 67 \\
\hline ELISA & 2 & 3.10 (1.99 to 4.81$)$ & 11 \\
\hline ECLIA & 2 & $1.60(0.76$ to 3.35$)$ & 64 \\
\hline Other & 2 & 6.64 (1.54 to 28.71$)$ & 93 \\
\hline \multicolumn{4}{|c|}{ Minimal severity of traumatic brain injury: } \\
\hline Mild & 4 & 4.29 (2.24 to 8.24$)$ & 84 \\
\hline Moderate & 1 & 2.13 (1.50 to 3.02$)$ & - \\
\hline Severe & 13 & 2.27 (1.68 to 3.06$)$ & 74 \\
\hline \multicolumn{4}{|l|}{ Isolated traumatic brain injury: } \\
\hline Isolated & 4 & 2.41 (1.67 to 3.48$)$ & 43 \\
\hline Multiple trauma or unspecified & 14 & 2.68 (1.92 to 3.73$)$ & 83 \\
\hline \multicolumn{4}{|l|}{ Blinding: } \\
\hline Blinded & 10 & $1.83(1.41$ to 2.37$)$ & 50 \\
\hline Unspecified & 8 & 3.56 (2.57 to 4.92$)$ & 73 \\
\hline
\end{tabular}

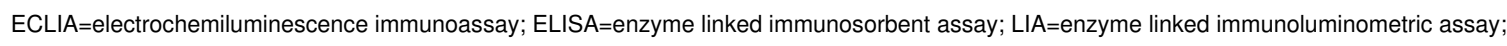
RIA=immunoradiometric assay. 
Table 4 | Summary of evidence for association of S-100 $\beta$ protein concentrations with mortality and unfavourable neurological outcomes in patients with traumatic brain injury

Outcome No of participants (studies) Quality of evidence (GRADE) GMR $(95 \% \mathrm{Cl})$

\begin{tabular}{llll} 
Mortality & $770(12)$ & Moderate & $2.55(2.02$ to 3.21$)$ \\
\hline GOS $\leq 3$ & $933(18)$ & Moderate & $2.62(2.01$ to 3.42$)$ \\
\hline
\end{tabular}

GMR=geometric mean ratio; GOS=Glasgow outcome score. 


\section{Figures}

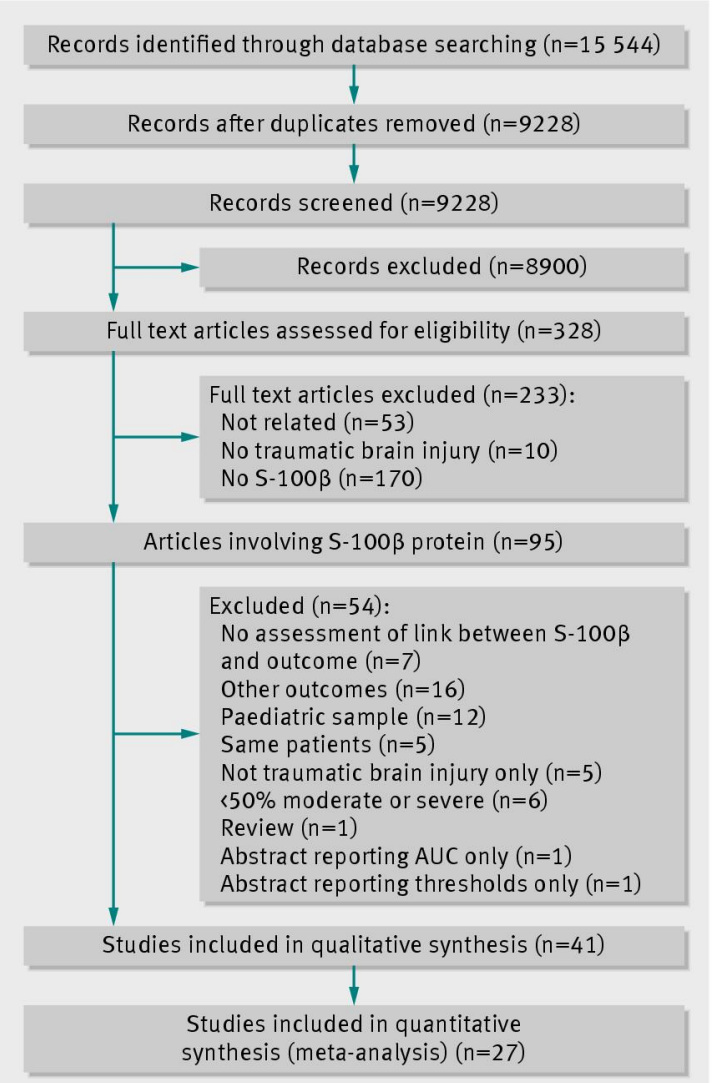

Fig 1 Identification of studies for inclusion in review of role of S-100 $\beta$ protein concentrations in prognosis in patients with moderate and severe traumatic brain injury

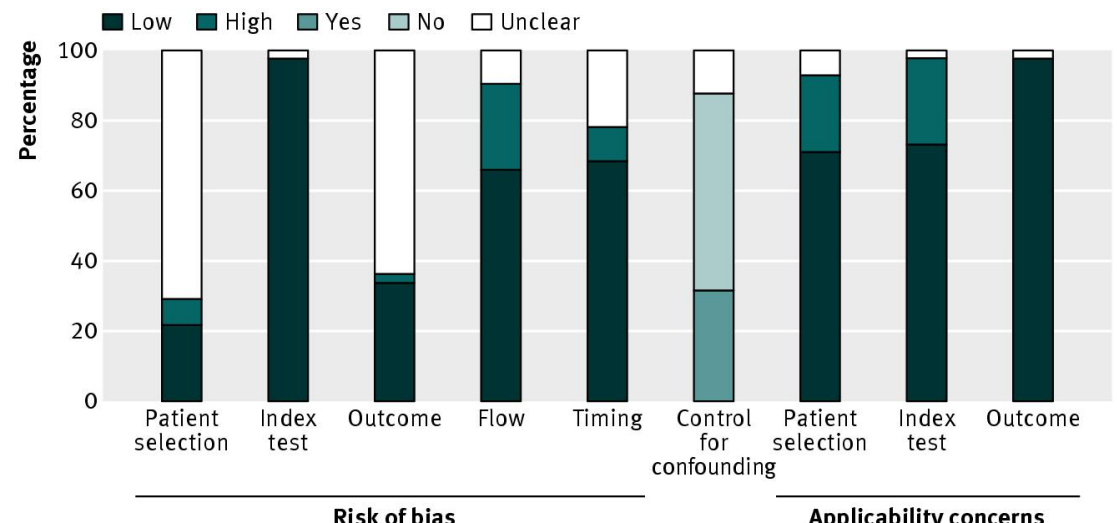

Fig 2 Risk of bias and applicability concerns of included studies examining role of S-100ß protein concentrations in prognosis in patients with moderate and severe traumatic brain injury 


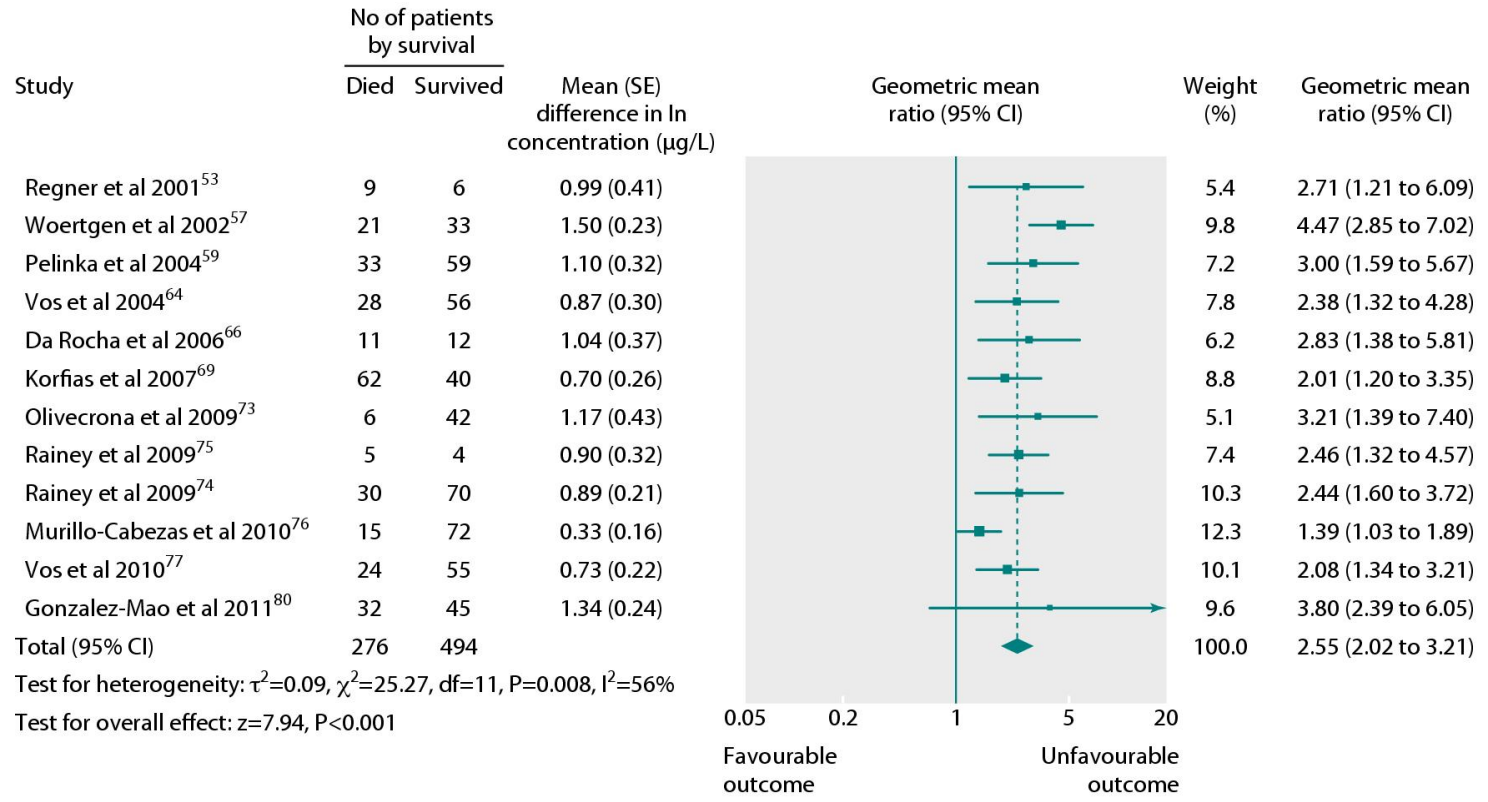

Fig 3 Association between S-100ß protein (shown as mean (SE) In transformed concentration) and mortality in patients with moderate and severe traumatic brain injury

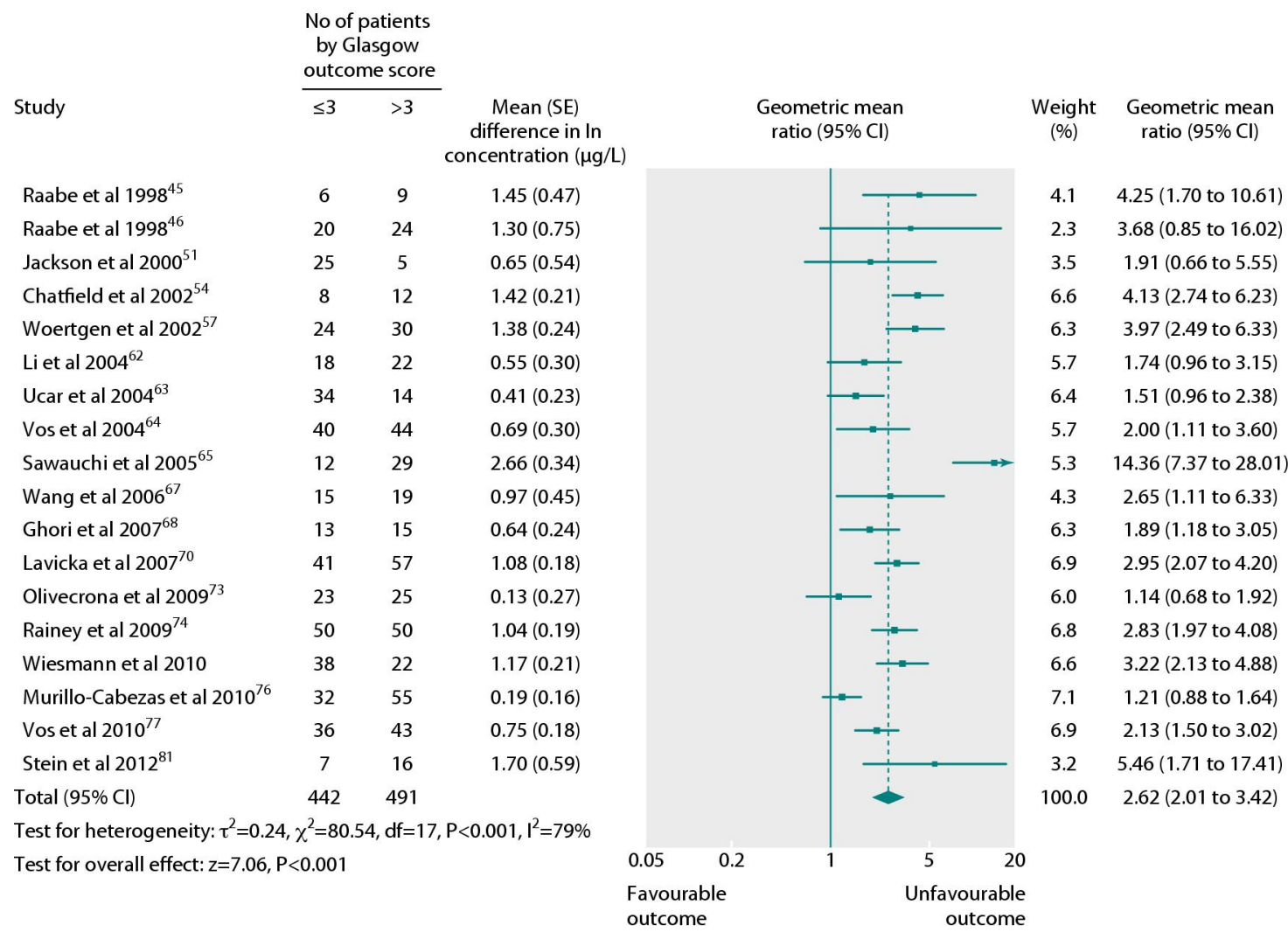

Fig 4 Association between S-100ß protein (shown as mean (SE) In transformed concentration) and Glasgow outcome score $\leq 3$ in patients with moderate and severe traumatic brain injury 

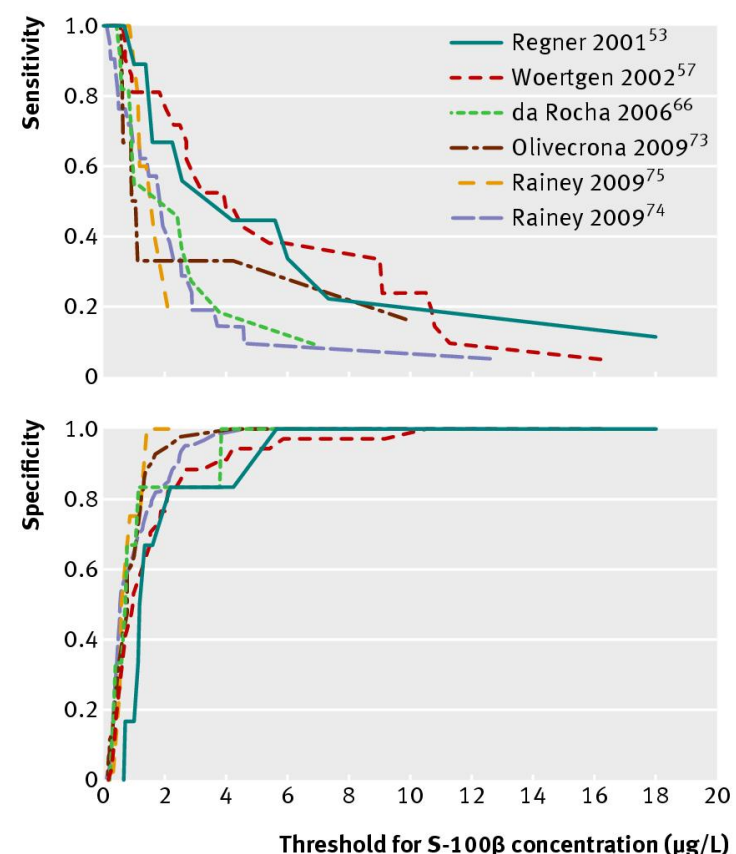

Fig 5 Sensitivity and specificity of prediction of mortality according to S-100ß protein concentrations ( $\mu$ g/L) in patients with moderate and severe traumatic brain injury
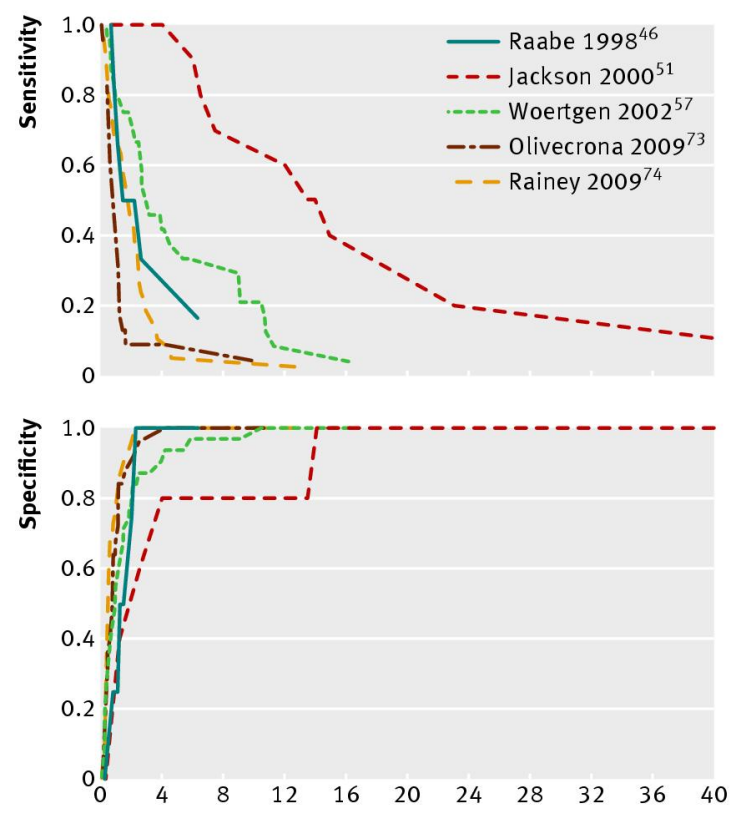

Threshold for S-100 3 concentration ( $\mu \mathrm{g} / \mathrm{L}$ )

Fig 6 Sensitivity and specificity of prediction of Glasgow outcome score $\leq 3$ according to S-100 $\beta$ protein concentrations $(\mu \mathrm{g} / \mathrm{L})$ in patients with moderate and severe traumatic brain injury 